\title{
The pursuit of happiness? Subjective wellbeing and internal migration in Great Britain
}

Link to publication record in Manchester Research Explorer

\section{Citation for published version (APA):}

Whittaker, W. (2014). The pursuit of happiness? Subjective wellbeing and internal migration in Great Britain.

\section{Citing this paper}

Please note that where the full-text provided on Manchester Research Explorer is the Author Accepted Manuscript or Proof version this may differ from the final Published version. If citing, it is advised that you check and use the publisher's definitive version.

\section{General rights}

Copyright and moral rights for the publications made accessible in the Research Explorer are retained by the authors and/or other copyright owners and it is a condition of accessing publications that users recognise and abide by the legal requirements associated with these rights.

\section{Takedown policy}

If you believe that this document breaches copyright please refer to the University of Manchester's Takedown Procedures [http://man.ac.uk/04Y6Bo] or contact uml.scholarlycommunications@manchester.ac.uk providing relevant details, so we can investigate your claim.

\section{OPEN ACCESS}


The pursuit of happiness? Subjective wellbeing and internal migration in Great Britain.

William Whittaker

University of Manchester

Correspondence:

Address: $\quad$ 4.304 Jean McFarlane

University of Manchester

Oxford Road

Manchester

M13 9PL

Phone: $\quad 01613068002$

Email: $\quad$ william.whittaker@manchester.ac.uk

\section{Keywords:}

Subjective wellbeing, internal migration, geographic health inequalities

JEL Classification codes:

C23, C36, C41 I10, J24, R23 


\begin{abstract}
:
In 2011 the UK government announced future plans to use subjective wellbeing as a measure of economic success. Understanding both the individual and geographic determinants of subjective wellbeing is important for future policy makers. Internal migration has important impacts on the geographic composition of populations, and if found to impact on individual wellbeing; could have significant effects on geographical variations in wellbeing.
\end{abstract}

The effect of internal migration on individuals has largely been focussed in the labour literature, assessing employment and earnings changes with migration. This paper assesses the effects of internal migration on subjective wellbeing in Great Britain. We use nationally representative data from the eighteen waves (1991-2008) of the British Household Panel Survey. The panel structure of the data is ideal for migration analysis, and the data contains a wide range of personal, labour market, and health characteristics of respondents. Migration is measured by residential moves. Wellbeing is measured using the 12-point version of the General Health Questionnaire. The effects of migration on the GHQ score are measured in the year following a move and by previous moving preference.

The methodology controls for the potential endogeneity of the migration decision and potential correlation between unobserved heterogeneity and the covariates. The results suggest the effects of migration differ by preference to move the previous period. Internal migration could have important impacts on geographic inequalities in wellbeing. 


\section{INTRODUCTION}

Recent government initiatives in Great Britain to formulate a subjective wellbeing yardstick as a measure of economic prosperity (ONS, 2011) mean understanding the determinants and structure of subjective wellbeing in the population is a prime concern for future policy initiatives.

There is a growing literature on the economics of subjective wellbeing (sometimes referred to as happiness), where it is assumed that changes in wellbeing reflect changes in utility borne out of individual behaviour and circumstance. Such measures are typically self-reported and it is the subjective element that is thought to better capture utility over more objective measures such as wage or income.

At the individual level, subjective wellbeing has been found to correlate with income, age, gender, ethnicity, education, health, work, and community involvement (Dolan et al. (2008) provide a comprehensive review). The methodology for identifying causal relationships between subjective wellbeing and individual characteristics or events has been focussed on whether to treat wellbeing scores as cardinal or ordinal data. Ferrer-i-Carbonell and Frijters (2004) found little difference in their results of linear (OLS) or ordinal (ordered Logit and Probit) models of wellbeing scores, but do find the treatment of individual fixed-effects important. Their paper is regularly cited as justification against ordinal modelling of wellbeing scores. Wellbeing has also been found to be persistent, several applications have analysed the dynamic process of subjective wellbeing (Hauck and Rice (2004) using the General Health Questionnaire (GHQ) and British Household Panel Survey (BHPS) data, and Contoyannis, Jones and Rice (2004) for self assessed health using the BHPS), finding 
evidence of significant persistence in wellbeing over time. The issue of whether ordinality or cardinality holds when modelling dynamic wellbeing is unknown.

At the geographical level, inequalities in wellbeing may exist due to compositional (the make-up of the population) or contextual (amenities and geographic-specific traits) factors. Several studies using longitudinal data on individuals and self-reported subjective wellbeing measures find little geographic variation in wellbeing. Weich et al. (2005) found small geographic variations using the BHPS and GHQ, Propper et al. (2005) found little evidence of significant geographic variations in GHQ (also using the BHPS) after controlling for individual and household effects, while McCulloch (2001) using GHQ and the BHPS found some evidence of geographic variation unexplained by individual and household characteristics. The general consensus is that the composition, rather than the contextual features of a region matter to geographical wellbeing variations. The composition of geographic populations is dependent on several dynamics: births, deaths, and international and internal migration.

In this paper we investigate the effects of internal migration on an individual's wellbeing in Great Britain. Individuals may migrate for a variety of reasons, whether they are pushed or pulled into migration will likely depend on the impact migration has on wellbeing. Migrants may also exhibit changes in wellbeing due to the likely changes in social capital and social networks (for example, Belot and Ermisch (2009) find friendship ties reduce the probability of migrating), and changes in labour force activity. These influences make hypotheses regarding the impacts of migration on wellbeing complex, yet important to our understanding 
of the effects of internal migration on individual wellbeing and hence, via the composition of populations, geographic inequalities in wellbeing.

\section{The migration decision}

To understand the causal relationship between migration and subjective wellbeing one needs to assess the migration decision-making process. The justification for migration works on the premise that migrants weigh up the migration decision as they would do an investment, by weighing up the (expected) costs and benefits of doing so (Sjaastad, 1962). In this context one may expect migrants to move if they expect to receive a net gain to their utility having moved.

The costs of migration are on the whole immeasurable, though studies on the determinants of migration have found migrants tend to be those most likely to face higher opportunity costs of not moving. For example, an unemployed individual is more likely to migrate as are those who are single, have no children, and are better educated (Hughes and McCormick, 1985, 1991; McCormick, 1997; Pissarides and Wadsworth, 1989; Boheim and Taylor, 2002; Andrews et al., 2011; Rabe and Taylor, 2012). In each case one can argue individuals are less tied to their residence and migration would be less costly.

The gains to migration have generally been assessed in the literature from a labour market perspective and have found negative employment effects and mixed earnings changes. For employment probabilities, Taylor (2007) found losses for both sexes in a study of residential moving couples using the BHPS, while Rabe (2011) found temporary losses only for females in dual-earner couples moving between Local Authority Districts (LADs) using the BHPS, 
Boyle et al. (2009) in a study of women in couples found losses for previously employed women and slight gains for previously unemployed women for moves of long distance $(>=30 \mathrm{~km})$ and for those moving for job related reasons; and Andrews et al. (2007) found losses for females at the Government Office Region level of migration using the BHPS. Studies analysing the effects of migration on earnings have found immediate (two year) gains for males migrating between Local Authority Districts (LADs) using the BHPS (Boheim and Taylor, 2007), and long-run gains for males and females migrating between regions for job related reasons using the BHPS (Andrews et al., 2007). In a study of migrating couples, Blackburn (2009) found little change in male earnings and a short-term decline in female earnings, this was largely robust across regional and long-distance moves.

The incorporation of subjective wellbeing into the migration decision represents a shift away from traditional empirical models of individual utility maximisation with wages or employment probability as the central criteria. The addition of subjective wellbeing as an argument in the decision process means the effect of migration is now based on an individual's self- perceived change in wellbeing, rather than objectively measured change in employment probability or earnings. Subjective wellbeing does not render employment and earning effects redundant, since wellbeing scores have been found to correlate with both earnings and employment (Blanchflower and Oswald, 2004; Clark and Oswald, 1994, 1996, 2007; Layard, 2005), but extends the measure of utility by also measuring potential costs and benefits that labour market measures alone would not. 
There are very few studies investigating the link between internal migration and subjective wellbeing. The few studies that exist have focused on the subjective wellbeing of labour force migrants in Thailand (De Jong et al., 2002) and rural-urban migrants in China (Knight \& Gunatilaka, 2008). These studies, though not directly comparable to the following analysis, do provide evidence of a significant negative impact of migration on wellbeing.

In a model of British migrants, Nowok et al. (2013) provide the single study we are aware of in a developed country setting. They model life satisfaction score against time preceding and proceeding migration. They find drops in life satisfaction a few years prior to a move, followed by an improvement in the year following a move, these results were largely robust to various specifications of migration (distance, gender, or motive). They find long-distance movers had higher rates of life satisfaction than short-distance movers before and after a move.

One approach to identify the effects of migration under the human capital framework is to assess subjective wellbeing on the basis of migrant motives. It seems logical that those who wanted to move may be more likely to experience gains in wellbeing than those who did not want to move. Whilst studies have used information on a migrant's reported reasons for moving (see for example, Boheim and Taylor (2002), Taylor (2007), Boyle et al (2009) and Nowok et al (2013) for analysis of job-related and tied movers), the reasons used do not explicitly identify whether the individual expressed a preference to move. 
Migration preferences have been exploited in models of the determinants of migration (see for example, De Groot et al., (2001); Coulter et al., (2011a, 2011b)) who find those expressing a preference to move are more likely to move the following year) but this information has not been used to analyse the effects of migration. Here we use information on moving preferences to provide an alternate assessment of the migration decision process and directly investigate whether migration effects differ by preference, and further, whether seemingly constrained individuals (non-migrants expressing a preference to move) exhibit relatively lower wellbeing scores to migrants.

Given migration preferences, the human capital model for the migration decision-making process may lead to the following hypotheses:

H1. Improvements in wellbeing scores for migrants compared to non-migrants for those that expressed a preference for moving

H2. Improvements in wellbeing scores for migrants who expressed a preference for moving compared to migrants who did not express a preference for moving

H3. Reductions in wellbeing scores for migrants compared to non-migrants for those that did not express a preference for moving

H4. Reductions in wellbeing scores for non-migrants who expressed a preference for moving compared to non-migrants who did not express a preference for moving

This paper aims to test hypotheses $\mathrm{H} 1-\mathrm{H} 4$ by analysing whether the effects of migration (and non-migration) on wellbeing differ by migration preferences for individuals moving within Great Britain using the first 18 waves (1991-2008) of the BHPS. To our knowledge this is the first paper to test whether perceived benefits (losses) to migration are realised. The results of 
the paper will help inform whether policy aimed at encouraging removing barriers to migration would benefit wellbeing scores and help inform the possible impacts migration has on regional inequalities in wellbeing.

The paper is structured as follows, section 2 describes the data used, section 3 details the models used in estimation with the results of these models given in section 4; section 5 concludes the paper with suggestions for further research.

\section{DATA}

We use the first eighteen waves (1991-2008) of the BHPS (University of Essex, 2010a). The BHPS is an annual survey launched in 1991 (Taylor et al. 2010). The first wave surveyed approximately 10,000 individuals (across 5,000 households). Respondents are surveyed annually and new respondents enter when children of original sample members reach 16, and when new relationships are formed with original sample members, as such, the household panel should remain broadly representative of households in Britain through time (Taylor et al. 2010).

The key benefit of using the BHPS is the ability to observe changes in residence with changes in an individual's personal and labour market characteristics. The BHPS contains rich data on moves, including distance moved, reason for a move, moving preferences, and several region of residence identifiers. In addition, the survey includes a number of selfreported health measures including Self Assessed Health, the GHQ-12, Life Satisfaction scores, and questions on a number of self-reported health problems. There is also a wide 
range of personal characteristics measured including age, gender, marital status, and an extensive job history section.

For the purpose of this study, we wish to model changes in wellbeing with migration and preference for migration. We observe all ages and gender, but exclude those living in Northern Ireland (since migration here is likely to reflect immigration rather than internal migration).

We define a migration as a change in residence in the last year. The BHPS dataset contains a derived indicator for individuals moving residence. The BHPS also contains derived data on the distance the individual has moved from their previous residence, however, this distance variable is constructed using the individuals last residence which may not be the address reported in the previous wave (should the individual had moved a number of times over the past year). As a result, distance moved is an imperfect proxy for distance moved since the previous wave.

We separate migrants and non-migrants by migration preference. Migration preference is defined by answers to the question 'If you could choose, would you stay here in your present home or would you prefer to move somewhere else?' This may signal whether someone expects a higher utility from moving than staying. Reasons for wanting to move are provided in the BHPS, respondents can choose from a range of household specific reasons, area reasons, occupation reasons, and others. We do not use this information to separate preferences for two reasons. First, this leads to small sample sizes, restricting the ability to 
identify an effect. Second, it is perhaps more likely that a combination of reasons lead the individual to prefer to move.

The BHPS also contains a question asking respondents whether they expect they will move in the coming year (even if they may not want to). Responses on expectancy and preference combined may provide a more potent identifier for those seriously considering moving. Expectations however, are only measured from wave 8 of the BHPS.

Using the longitudinal structure of the data we can identify individuals that have moved between $t$ and $t-1$, and the preference for a move at $t-1$. We create four mutually exclusive dummy groups: migrants who preferred to move, non-migrants who preferred to move, migrants who did not prefer to move, and non-migrants who did not prefer to move. This enables us to test our hypotheses (H1-H4) directly.

To model wellbeing changes we use the GHQ-12 (Goldberg et al., 1997) which is asked in each wave of the BHPS. The GHQ-12 asks respondents twelve questions related to their health, feelings, and self-perceptions and explicitly asks respondents to compare recent weeks to usual, the twelve questions include:

Have you recently...

Been able to concentrate on whatever you are doing?

Lost much sleep over worry?

Felt that you are playing a useful part in things?

Felt capable about making decisions about things? 
Felt constantly under strain?

Felt you could overcome your difficulties?

Been able to enjoy your day-to-day activities?

Been able to face up to your problems?

Been feeling unhappy and depressed?

Been losing confidence in yourself?

Been thinking of yourself as a worthless person?

Been feeling reasonably happy, all things considered?

From the four possible answers, "Not at all", "No more than usual", "Rather more than usual", and "Much more than usual"; the BHPS records a 12 point score (GHQ-12) comprising of each question transformed into a binary indicator for negative (one) and positive (zero) responses. The GHQ-12 ranges from 0 to 13 (sometimes termed 'Caseness score'). Those with higher scores represent worse wellbeing.

The GHQ-12 has been reported as a valid measure of mental illness. Goldberg et al. (1997) find median sensitivity (correctly identifying individuals as cases) and specificity (the proportion of individual cases correctly identified) rates of $83.7 \%$ and $79.0 \%$ respectively across the several studies spanning nine countries. Best thresholds for the Clinical Interview Schedule and Present State Evaluation were 3.13 and 3.17 respectively.

Using data from a World Health Organisation study across 15 countries, Goldberg et al. (1997) assess the validity of GHQ-12 as an indicator of current depression, dysthymia, 
agoraphobia, panic disorder, generalized anxiety disorder, somatisation disorder, neurasthenia and hypchondriasis. These were measured using the ICD-10 (International Classification of Disease, $10^{\text {th }}$ edition), and DSM-IV (Diagnostic and Statistical Manual of the American Psychiatric Association, $4^{\text {th }}$ edition), with and without anxiety, and with and without alcohol dependence. The mean area under the Receiver Operating Characteristic (ROC) curves was 0.88 , overall sensitivity was $83.4 \%$ and specificity $76.3 \%$. The average threshold across all centres was $2 / 3$.

Although GHQ-12 is used as a signal for mental illness, it has also been found to be a valid instrument for general wellbeing. Factor analysis of the items in the GHQ-12 have found depression and anxiety to be the most dominant factors of the GHQ-12 (Shevalin and Adamson., 2005; Kalliath et al., 2004; Martin, 1999; Schmidt et al., 1999; Graetz, 1991). The GHQ-12 has also been found to be robust to retest effects in the BHPS (Pevalin, 2000).

A binary measure (based on a cut-off score of the GHQ-12) has been used in past studies assessing geographic variation (Weich et al, 2005, McCulloch, 2001; Propper et al, 2005), and as mentioned above, has been validated as an indicator for a range of psychosocial mental health measures. Modelling GHQ-12 as a binary variable however, while permitting much more flexibility in estimation, loses potential gradient effects of migration to be modelled, for this reason we model the GHQ 12-point score ('GHQ').

It is important to note here that though GHQ will be correlated with physical health, the mental health measure was chosen over more physical health measures as any effect of 
migration will likely reveal itself through mental changes rather than physical. To control for any physical health effect on the wellbeing estimate, we generated and included a binary indicator for physical health problems. This equals one if the respondent self-reports problems with: arms/legs, sight, hearing, skin, chest, heart/blood, liver, diabetes, epilepsy, and migraine.

Alternative measures of wellbeing are available in the BHPS. Satisfaction with life is measured in waves 6-10 and waves 12-18. The intermittent prevalence of life satisfaction data inhibits the analysis, particularly since we later require individuals to be present in two adjacent waves (this further drops waves 6, and 12 from the analysis). Self Assessed Health is asked in waves 1-8 and waves 13-18. In addition to data loss, Self Assessed Health is not used in this analysis since this may be more indicative of physical health and less sensitive to subjective wellbeing variations.

\section{METHODOLOGY}

To model subjective wellbeing we need to control for several potential sources of endogeneity. First, subjective wellbeing is likely to prompt intra-person comparisons on health, the individual answering the questions that form GHQ are explicitly asked to compare their circumstance to 'usual'. Second, the individual heterogeneity inferred to above is likely to be correlated with controls we have in the model, for example, if some individuals are perhaps more pessimistic in their attitudes towards health this may also reflect in a general (observed) pessimism towards work and family life. Third, health is likely to by persistent, correlated by past health status. 
Controlling for unobserved heterogeneity that is correlated with the covariates in the model is difficult when the dependent variable is ordinal. One approach is to estimate the Chamberlain (1980) conditional-logit model. Here the dependent variable is transformed into a binary indicator for poor wellbeing, and the sample size is restricted to include only those individuals who vary in their wellbeing scores over the sample. There are numerous approaches available to empirically determine what the cut-off level of GHQ should be (see for example Ferrer-i-Carbonell and Frijters (2004), Das and Van Soest (1999), and Baetschmann et al. (2011)). Regardless of the approach taken, the need to determine a cut-off GHQ score loses information on the effects of migration on wellbeing, both due to reduced variation and in the restriction of sample size.

An alternative approach could be to treat the dependent variable as cardinal and estimate the fixed-effects estimator, this approach has been taken by many studies in the wellbeing literature with the justification given by the seminal paper by Ferrer-i-Carbonell and Frijters (2004) who found similar estimates of the covariates (sign, significance, and size) in linear and ordinal models. Though the justification is compelling and significantly simplifies the methodology, the fixed-effects approach is not valid in our analysis due to the dynamic component of the model. Linear dynamic modelling approaches are needed, such as those by Arellano and Bond (1991). Arellano and Bond show how differencing the linear model (to remove the time-invariant individual heterogeneity term) and instrumenting lags of the dependent variable with higher level lags (to remove the endogeneity of the lagged dependent variable with the error term) results in consistent estimates. 
To control for the potential sources of endogeneity without restricting the dependent variable to be cardinal, we employ the dynamic ordered probit with unobserved effects model proposed by Wooldridge (2005). This approach enables GHQ to be measured as an ordinal variable, permits the modelling of individual heterogeneity, and enables the estimation of GHQ in a dynamic setting.

To begin with, equation (1) below models GHQ $\left(y_{i t}\right)$ against lagged GHQ $\left(y_{i t-1}\right)$, and a range of covariate $\left(z_{i t}\right) . c_{i}$ is an individual specific time invariant error term. $u_{i t}$ is an individual specific error term, assumed to be strictly exogeneous.

$$
y_{i t}=\beta_{0}+\beta_{1} z_{i t}+\beta_{2} y_{i t-1}+c_{i}+u_{i t}
$$

$z_{i t}$ contains dummies for having moved in the past year by moving preference at $t-1 . z_{i t}$ also contains information on age, marital status, ethnicity, social class (the Registrar Generals definition with status inferred from the individuals current job, last job, fathers status, mothers status, and head of household status in order where missing data is provided), education, number of children, physical health problems, region identifiers, employment status, and household income. $y_{i t-1}$ contains a dummy for each of the thirteen (0-12) GHQ scores possible in the previous wave.

We model all moves by an individual, since the first observed move in the data need not be the first move for that individual over their existing lifetime. To mitigate any potential bias caused by modelling multiple moves, we include dummies for the total number of observed moves made by that individual over the sample. 
Since the dependent variable (GHQ) is ordinal, we estimate ordered response models whereby an underlying latent variable, $y^{*}$, is modelled such that:

$$
y_{i t}^{*}=\beta_{0}+\beta_{1} z_{i t}+\beta_{2} y_{i t-1}+c_{i}+u_{i t}
$$

With $y_{i t}$ indicating whether $y^{*}$ falls within particular ranges of estimated cut-points $\left(\tau_{j}\right)$ :

$y_{i t}=j \quad$ if $\quad \tau_{j-1}<y_{i t}^{*} \leq \tau_{j}$

and $y_{i t}=1 \quad$ where $y_{i t}^{*} \leq \tau_{1}$

and $y_{i t}=J \quad$ where $y_{i t}^{*} \geq \tau_{J}$.

$\tau_{j}$ permits differences between thresholds of each outcome in the dependent variable. Hence the estimation procedure permits distances between scores to be of varying magnitude, a covariate estimate may hence have different impacts on the probability of each GHQ score. Treating the dependent variable as continuous would impose the restriction that the cut points have equivalent distances.

The response probabilities of each value of $y_{i t}$ are hence:

$$
\begin{aligned}
P\left(y_{i t}=j\right)= & P\left(\tau_{j-1}<y_{i t}^{*} \leq \tau_{j}\right) \\
& =\Phi\left(\tau_{j-1}-\beta_{1} z_{i t}-\beta_{2} y_{i t-1}-c_{i}\right)-\Phi\left(\tau_{j}-\beta_{1} z_{i t}-\beta_{2} y_{i t-1}-c_{i}\right)
\end{aligned}
$$

Where $\Phi($.$) is the normal cumulative distribution function.$

With log-likelihood:

$$
\begin{aligned}
& l_{i}\left(\tau_{1}, \ldots, \tau_{J}, \beta_{1}, \beta_{2}\right) \\
& \quad=\sum_{i=1}^{n} \ln \left[\Phi\left(\tau_{j-1}-\beta_{1} z_{i t}-\beta_{2} y_{i t-1}-c_{i}\right)-\Phi\left(\tau_{j-1}-\beta_{1} z_{i t}-\beta_{2} y_{i t-1}-c_{i}\right)\right]
\end{aligned}
$$


Wooldridge (2005) specifies the individual time invariant error term, $c_{i}$, as a normally distributed term and includes the initial observation of $y_{i t}\left(y_{i 0}\right)$ and the time averages of the time varying covariates in $z_{i t}\left(z_{i}\right)$ such that:

$$
c_{i}=a_{0}+a_{1} y_{i 0}+a_{2} z_{i}+\delta_{i}+\varepsilon_{i t}
$$

with

$$
\begin{aligned}
& c_{i} \mid\left(y_{i 0}, z_{i t}\right) \sim \operatorname{Normal}\left(a_{0}+a_{1} y_{i 0}+a_{2} z_{i}, \sigma_{\delta}^{2}\right) \\
& \delta_{i} \mid\left(y_{i 0}, z_{i t}\right) \sim \operatorname{Normal}\left(0, \sigma_{\delta}^{2}\right)
\end{aligned}
$$

Substituting (2) into (1) leads to a final underlying latent variable specification:

$$
y_{i t}^{*}=\beta_{0}+\beta_{1} z_{i t}+\beta_{2} y_{i t-1}+a_{0}+a_{1} y_{i 0}+a_{2} z_{i}+\delta_{i}+e_{i t}
$$

with

$$
e_{i t} \mid\left(z_{i t}, y_{i t-1}, y_{i 0}, z_{i}, \delta_{i}\right) \sim \operatorname{Normal}(0,1)
$$

and resulting log-likelihood:

$$
\begin{aligned}
l_{i}\left(\tau_{1}, \ldots, \tau_{J}, \beta_{1}, \beta_{2}, a_{1}, a_{2}\right) & \\
= & \sum_{i=1}^{n} \ln \left[\Phi\left(\tau_{j-1}-\beta_{1} z_{i t}-\beta_{2} y_{i t-1}-a_{1} y_{i 0}-a_{2} z_{i}-\delta_{i}\right)\right. \\
& \left.-\Phi\left(\tau_{j-1}-\beta_{1} z_{i t}-\beta_{2} y_{i t-1}-a_{1} y_{i 0}-a_{2} z_{i}-\delta_{i}\right)\right]
\end{aligned}
$$

Integrating the unobserved heterogeneity term $\delta_{i}$ (using Gaus-Hermite quadrature) leads to a log-likelihood that can be estimated with standard random effects ordered probit software:

$$
\begin{aligned}
& l_{i}\left(\tau_{1}, \ldots, \tau_{J}, \beta_{1}, \beta_{2}, a_{1}, a_{2}\right)=\sum_{i=1}^{n}\left\{\operatorname { l n } \int _ { - \infty } ^ { + \infty } \prod _ { t = 1 } ^ { T } \left[\Phi \left(\tau_{j-1}-\beta_{1} z_{i t}-\beta_{2} y_{i t-1}-a_{1} y_{i 0}-a_{2} z_{i}-\right.\right.\right. \\
& \left.\left.\left.\delta_{i}\right)-\Phi\left(\tau_{j-1}-\beta_{1} z_{i t}-\beta_{2} y_{i t-1}-a_{1} y_{i 0}-a_{2} z_{i}-\delta_{i}\right)\right]\left[\left(\frac{1}{\sqrt{2 \pi \sigma_{\delta}^{2}}}\right) \exp \left(-\frac{\delta^{2}}{2 \sigma_{\delta}^{2}}\right)\right] d \delta\right\}
\end{aligned}
$$


The inclusion of the initial condition is necessary both for the dynamics estimation of the dependent variable, but also as an indicator of the left-censored nature of the BHPS dataset. The time averages, $z_{i}$, while forcing non-time varying covariates out of $z_{i t}$; are assumed to account for all correlation of the unobserved heterogeneity with the covariates in $z_{i t}$.

Equation (3) assumes that (i) having conditioned on the covariates and unobserved heterogeneity: $z_{i}$ and $c_{i}$, the dynamics are correctly specified as first order, (ii) $c_{i}$ is additive in the standard normal cumulative distribution function, and (iii) the $z_{i t}$ are strictly exogenous. Equation (3) is estimated using xtoprobit in STATA v13.0.

Estimates from an ordinal model are interpreted with respect to where an individual lies on the GHQ scale (in other words, on the cut-points estimated). This complicates the interpretation of the estimates. In addition, estimates from non-linear models need to be transformed into marginal effects to translate the estimated effect into probability impacts. The estimates are translated into average marginal effects using STATA's margins command. The average marginal effect estimates the average effect (over each observation rather than at the sample mean) of a discrete change in the respective covariate on the predicted probability of a specific value of wellbeing. We specify the random effect to be at the (mean) value of zero. Standard errors are calculated using the delta method.

There is another potential enogeneity issue, migrants are selective in health, tending to be the healthy young and ill old (Norman et al. (2005) using the England and Wales Longitudinal Survey for 1971-1999 and limiting long-term illness; Verheij et al. (1998) using the 1991- 
1995 waves of the Dutch Longitudinal Study on Socio-Economic Health Differences and self-reported health status; Bentham (1988) using the 1971/81 Great Britain Census and selfreported work incapacity). The health of migrants is also found to vary by distance moved with long distance movers reporting lower limiting long-term illness (Boyle et al., 2002; Bentham, 1988). If healthy people migrate, then the estimates of the migration dummy will be negatively biased. The inclusion of lagged GHQ mitigates this endogeneity, we are in effect controlling for GHQ at the time of migration by the inclusion of lagged GHQ (stripping the bias caused by positive or negative associations between migration and GHQ from the migration estimate).

We model three specifications for migration. The first is where we model the effects of residential migration, in the second specification we split the migration dummy by moving preference, in the third specification we estimate by gender and test for any differences in the estimates between males and females.

\section{RESULTS}

From the full BHPS sample of 224,840 person-year observations, excluding those in Northern Ireland and the first wave each individual is observed (since migration is undefined here), and those with no GHQ and/or lagged GHQ data results in a sample of 168,092 person-years (19,235 individuals of which 9,126 are male and 10,109 female). Excluding data with no manual status, ethnicity, education, marital status, child data, physical health data, job status, or regional identifier gives our final sample size of 132,466 person-years 
(16,431 individuals of which 7,672 are male and 8,759 female). Summary statistics of all variables used in the analysis are provided in the appendix.

[Table I here]

Table I gives the migration rates and respective moving preference rates the previous wave. $9.69 \%$ of the sample move residence at some point over the survey $(9.80 \%$ of males and $9.61 \%$ of females). This is slightly lower than the average residential migration rate of 12.18\% in Census data for 2001 (Office for National Statistics, 2004), though the Census data is for England and Wales and includes international migrants moving into the UK. Of those who did not migrate, $30.69 \%$ expressed a preference to move in the previous wave $(31.14 \%$ and $30.31 \%$ for males and females respectively), this is lower than the average moving preference of $61.58 \%$ (60.83\% and $62.22 \%)$ for migrants.

[Table II here]

Average GHQ scores are provided in Table II. Migrants have worse GHQ scores than nonmigrants (2.13 compared to 1.82 , recall a lower GHQ score is indicative of better wellbeing) both before and after a move for all types of moving preference and gender. Comparisons of GHQ scores at time $t$ to $t-1$ for non-migrants suggest GHQ is fairly persistent. For migrants, GHQ scores appear to improve following a move (2.13 from 2.25 before migration). Improvements in GHQ score are largest (in absolute terms) for those migrants who expressed a preference to move in the previous wave. The largest improvement in GHQ is observed for female migrants who preferred to move (GHQ falls by 0.20 points). Migration looks to 
improve subjective wellbeing, the effect is larger for those who expressed a preference to move.

Table II highlights the need to control for the endogeneity of migration in the model for GHQ scores. A cross-sectional comparison of migrants to non-migrants would imply migration is detrimental to wellbeing. Yet conditioning on past GHQ status reveals that migrants have relatively better GHQ scores after a move.

Table III presents four sets of results. The first is the unconditional average effect of migration on GHQ, the estimate is obtained from an ordered probit model of GHQ, migrants have an estimated higher GHQ score than non-migrants. Interpretation of the magnitude of the effect is in relation to the cut-point estimates. The second specification splits the migration dummy by preference to move at $t-1$. The base is non-migrants who preferred not to move at $t-1$. As the average rates revealed in Table II, GHQ is higher (therefore worse) for non-migrants who preferred to move, and all migrants irrespective of moving preference. The third and fourth specifications include lagged GHQ, the estimates for those that migrate decrease substantially, suggesting that migration estimates in a model that does not condition on lagged GHQ are biased upwards. Similar effects are found for non-migrants who preferred to move.

[Table III here]

Table IV contains the estimates for the migration dummies obtained from a dynamic random effects ordered probit model for residential migration. The models include the full set of 
covariates (the full set of estimates are included in Table A 2 in the appendix). We find significant differences between males and females (a Chow test of equal estimated coefficients was rejected, $\mathrm{p}$-value $<0.001)$. Rho calculates the intra-class correlation coefficient $\left(\sigma_{u}^{2} /\left(1+\sigma_{u}^{2}\right)\right)$ and is interpreted as the proportion of the error variance captured by unobserved individual heterogeneity.

[Table IV here]

Table V contains the estimated average marginal effects for the migration dummies obtained from a dynamic random effects ordered probit model for residential migration. The average marginal effects are given for each potential GHQ score and are relative to the base of nonmigrants who preferred not to move. The estimated average marginal effects show how, in the ordinal framework, a covariate can have different impacts on each ordered category. In the 'All' sample for example, migration reduces the probability of the individual reporting a GHQ score of zero (by 0.8 percentage points), but increases the probability of the individual reporting any GHQ score greater than zero (by 0.1 percentage points for a GHQ score of one to 0.05 percentage points for a GHQ score of twelve).

For both genders we find no significant improvements in GHQ for migrants compared to non-migrants for those expressing a preference to move (hypothesis $\mathrm{H} 1$ ); no significant difference in the effects of migration by preference to move (hypothesis $\mathrm{H} 2$ ); and no significant difference in GHQ scores for migrants and non-migrants who did not express a preference to move (hypothesis H3). We find significantly lower GHQ scores for males who 
expressed a preference to move but did not, compared to non-migrants who did not express a preference to move (hypothesis H4).

[Table V here]

The effects of the additional covariates are largely robust, GHQ is higher for those who become widowed, those single, and for those with physical health problems. We find no significant effect of multiple migrations for the individual (total number of migrations) observed in the BHPS. We find no effect of income and positive (worse) GHQ for those unemployed, retired, in family care, and the long-term sick compared to the employed. For each of the time-varying covariates, there is also a time-averaged counterpart. Effectively the covariates represent changes, with the time-averages a more long-term effect, however, by assumption the time-averaged covariates are meant to pick up any unobserved heterogeneity correlated with the covariates (see Equation (2)), the interpretation of the time-averaged covariate estimates are somewhat problematic, representing associations of the covariates with the unobserved heterogeneity term.

There are several issues with the modelling of both subjective wellbeing and migration. First relating to the measurement of subjective wellbeing and migration, second the methods used to model wellbeing and migration, and third how to deal with attrition for both subjective wellbeing and migration.

To assess whether the effects of migration were robust to wellbeing measures, we replicated the analysis using self-reported life satisfaction scores (see Online Resource 1). The analysis 
for GHQ was estimated on the same sample size as that of the life satisfaction model (since life satisfaction is not available in all waves of the BHPS). Though not directly comparable due to the differences in the estimates cut-points, we find different effects of migration for life satisfaction. Unlike GHQ scores, we also find migration has a significant impact on life satisfaction and significant differences for those seemingly forced to move (migrants with a prior preference not to move) and those constrained (non-migrants with a prior preference to move).

To model whether longer distance moves may have larger effects on wellbeing, we extend the analysis to investigate migrations between LADs using the special access BHPS dataset to obtain LAD identifiers for individuals (University of Essex, 2010b). LAD moves have previously been used in the literature and has a more direct policy relevant impact. There are 408 LADs in Great Britain. Although we want to observe movements away from the local neighbourhood, geographic barrier crossing such as LAD migrations in our data could still include those moving a short distance.

We might expect that movements of longer distance correspond with greater wellbeing effects. The results however, suggest longer distance moves have no impact on migrants irrespective of preference to move and for non-migrants who expressed a preference to move (see Online Resource 2).

Attrition is a key concern in longitudinal studies, this is particularly important when assessing health and migration, since attrition may be higher amongst the ill (Contoyannis et al., 2004) and those that migrate (Buck, 2000). We modelled the dynamic ordered probit model for the 
'All' sample (males and females) with three additional variables to formally test for attrition bias, these were (i) whether the individual was present in the next wave, (ii) whether the individual was present in all waves, and (iii) the number of waves present for the individual (Verbeek and Nijman, 1992). A negative and significant estimate was found for whether the individual was present in the next wave $(-0.0911, \mathrm{p}<0.001)$, this suggests attritors are less likely to report better wellbeing scores. To assess how robust our findings are we replicated our analysis modelling only the balanced panel to see whether the results changed when using only this group. Although comparisons between the estimates are not possible due to the separate cut-point estimates, our results suggest the significance of the migration dummies are robust to whether the unbalanced or balanced sample are used (see Online Resource 3).

\section{DISCUSSION}

We use longitudinal data containing rich information on moving, preference for moving, health, personal, and labour market characteristics. We find no significant effect of migration on GHQ, but a significant worse GHQ score for males wanting to move but not doing so. To our knowledge this is the first study to incorporate stated preferences for moving into an analysis of the effects of migration on wellbeing. Human Capital theory would hypothesise that migrants who had stated a previous preference to move do so in relation to their expectation of gains or losses from moving. The implications of the results for the Human Capital approach to migration are mixed. Though migrants exhibit no worsening in wellbeing score, they also appear to exhibit no improvement. This may be a composite effect of changes in social networks, housing, and familial structures. Future research on decomposing the 
effects of these changes on wellbeing would prove fruitful. Our results do, however, find evidence of a deterioration of wellbeing for those wanting to move but failing to do so. Policy that helps individual's realise their preferences for moving (perhaps by encouragement and support to facilitate a move) could help reduce the damaging effects of stayers preferring to move on subjective wellbeing.

The approach we have taken may capture an immediate effect of migration, but there may be good reason to believe the effects of migration on health vary with time. While migration may result in the breakdown of familial and friendship networks, individuals could take some years to fully assimilate to the new residence, building social networks and local knowledge. In this instance it seems plausible to expect long-run effects on health. The dynamic structure of the model reveals that the effects of migration will be felt for years following a move (due to the high correlation between GHQ score and lagged GHQ score).

The movement of individuals between geography is not accounted for in standard geographic comparisons in health and has been cited as a main criticism in the modelling of health inequalities (Connolly et al., 2007). Of particular concern is the health of migrants, the flow of healthy migrants out of deprived areas and into less deprived areas could have potentially serious distorting effects on cross-sectional comparisons of health inequalities.

The literature on health inequalities and migration has been limited by data availability, typically looking at the health of migrants post-movement. Changes in inequalities are measured by placing migrants back into their origin and comparing how this changes 
inequalities in health (see for example, Connolly et al., (2007); Norman et al., (2005); and Brimblecombe et al., (1999)). None of these studies have assessed how migration impacts on the health of the migrant. If migration has an impact on migrant health then placing migrants back into their origin may under- or over-state the influence they have on health inequalities. This is of particular concern with subjective wellbeing. Our results suggest placing migrants back into their previous residence may not bias models of geographic inequalities in wellbeing.

There are several limitations to the study. We assume that an individual's preference to move does not change between time $t-1$ and our observed migration at time $t$. However, changes in individual circumstances, be it relationship dissolution or formation, or labour market changes for example, would likely change an individual's preference to move.

Our results differ depending on the measure of wellbeing chosen. GHQ and life satisfaction scores may be identifying different aspects of the utility function.

The study focuses on individual wellbeing, but migration is likely to be at the household level. Over $70 \%$ of the sample report being in a relationship. Further research on the measurement of household wellbeing and bargaining would be insightful.

Limitation withstanding, our results lead to several key conclusions. First, migration does not harm individual wellbeing; GHQ scores are not significantly different by prior moving preference. Second, longer distance moves are not associated with stronger wellbeing effects. 
Third, females (who have been largely considered 'tied' movers in the literature) experience no significant effect of migration on their wellbeing scores. Fourth, males seemingly restrained to their residence exhibit lower wellbeing scores than migrants and those preferring not to move.

Our results lead to a number of policy implications. First, policies aimed at freeing up individuals who want to migrate but find it difficult to translate this into a move could improve wellbeing. Second, the lack of change to wellbeing for migrants suggest existing approaches to measure the impacts of migration on geographical wellbeing inequalities are justified. Placing migrants back into their region of origin would not bias the contribution of migration to geographical inequalities in wellbeing.

\section{Acknowledgements:}

The author would like to thank Martyn Andrews and Ken Clark at the University of Manchester, Aki Tsuchiya and colleagues at the Economics department at the University of Sheffield, the Institute for Economic and Social Research at the University of Essex, and Newcastle University Business School for their useful comments and suggestions.

\section{Funding:}

Whittaker was funded by the MRC/NIHR/ESRC Early Careers Post Doctoral Fellowship in Health Economics (G0902072) 


\section{REFERENCES}

Andrews, M.J., Clark, K. \& Whittaker, W. 2007. The Employment and Earnings of Migrants in Great Britain. IZA Discussion Paper no.3783.

Andrews, M.J., Clark, K. \& Whittaker, W. 2011. The determinants of regional migration in Great Britain: A duration approach. Journal of the Royal Statistical Society: Series A (Statistics in society) 174(1): 127-153.

Arellano, M. \& Bond, S. 1991. Some tests of specification for panel data: Monte Carlo evidence and an application to employment equations. The Review of Economic Studies 58: 277-297.

Baetschmann, G., Staub, K.E., \& Winkelmann, M.R. 2011. Consistent estimation of the fixed effects ordered logit model. IZA Discussion Paper no. 5443.

Bentham, G. 1988. Migration and morbidity: implications for geographical studies of disease. Social Science \& Medicine 26: 49-54.

Blackburn, M.L. 2009. The impact of internal migration on married couples' earnings in Britain. Economica 77: 584-603.

Blanchflower, D.G. \& Oswald, A.J. 2004. Well-being Over Time in Britain and the USA. Journal of Public Economics 88: 1359-1386.

Boheim, R. \& Taylor, M.P. 2002. Tied down or room to move? Investigating the relationships between housing tenure, employment status and residential mobility in Britain. Scottish Journal of Political economy 49(4): 369-392.

Boheim, R. \& Taylor, M.P. 2007. From the Dark End of the Street to the Bright Side of the Road? The Wage Returns to Migration in Britain. Labour Economics 14(1): 99-117.

Boyle, P. J., Norman, P., \& Rees, P. H. 2002. Does migration exaggerate the relationship between deprivation and limiting long-term illness? A Scottish analysis. Social Science \&Medicine 55: 21-31.

Boyle, P., Feng, Z., \& Gayle, V. 2009. A new look at family migration and women's employment status. Journal of Marriage and Family 71: 417-431.

Brimblecombe, N., Dorling, D., \& Shaw, M. 1999. Mortality and migration in Britain, first results from the British Household Panel Survey. Social Science \& Medicine 49: 981-988.

Buck, N.H. 2000. Using panel surveys to study migration and residential mobility. In Rose, D, (ed), Researching Social and Economic Change, London:Routledge.

Chamberlain, G. 1980. Analysis of covariance with qualitative data. Review of Economic Studies 47(1): 225-238. 
Clark, A.E. \& Oswald, A.J. 1994. Unhappiness and Unemployment. Economic Journal 104: 648-659.

Clark, A.E. \& Oswald, A.J. 1996. Satisfaction and Comparison Income. Journal of Public Economics 61: 359-381.

Clark, A.E., \& Oswald, A.J. 2007. 'The Curved Relationship Between Age and Subjective Well-being.' Working paper, PSE, Paris.

Connolly, S., O’Reilly, D., \& Rosato, M. 2007. Increasing inequalities in health: Is it an artefact caused by the selective movement of people? Social Science \& Medicine 64:20082015.

Contoyannis P, Jones A.M, \& Rice N. 2004. The dynamics of health in the British Household Panel Survey. Journal of Applied Econometrics 19: 473-503.

Coulter, R. \& van Ham, M. 2011. Contextualised mobility histories of moving desires and actual moving behaviours. IZA Discussion Paper no.6146.

Coulter, R., van Ham, M., \& Feijten, P. 2011. A longitudinal analysis of moving desires, expectations and actual moving behaviour. Environment and Planning A 43: 2742-2760.

Das, M. \& Van Soest, A. 1999. A panel data model for subjective information on household income growth. Journal of Economic Behavior \& Organisation 40(4): 409-426.

De Groot, C., Mulder, C., Das, M., \& Manting, D. 2011. Life events and the gap between intention to move and actual mobility. Environment and Planning A 43: 48-66.

Department of Health. 2011. Resource Allocation: Weighted Capitation Formula. Seventh Edition.

Dolan, P., Peasgood, T., \& White, M. 2008. Do we really know what makes us happy? A review of the economic literature on the factors associated with subjective well-being. Journal of Economic Psychology 29: 94-122.

Ferreira, P., \& Taylor, M. 2009. Residential mobility, mobility preferences and psychological health. In M Brynin \& J. Ermisch (Eds.), Changing relationships (pp. 161-179). Oxford: Routledge.

Ferrer-i-Carbonell, A. \& Frijters, F. 2004. How important is methodology for the estimates of the determinants of happiness? Economic Journal 114(97): 641-659.

Ferrer-i-Carbonell, A., \& Gowdy, J. M. 2007. Environmental degradation and happiness. Ecological Economics 60(3): 509-516.

Frechette, G.R. 2001. Random-effects ordered probit. Stata Technical Bulletin 59: 23-27. 
Goldberg, D.P., Gater, R., Sartorius N., Ustun, T.B., Piccinelli, M., Gureje, O., \& Rutter, C. 1997. The validity of two versions of the GHQ in the WHO study of mental illness in general health care. Psychological Medicine 27: 191-197.

Graetz, B. 1991. Multidimensional properties of the General Health Questionnaire. Social Psychiatry and Psychiatric Epidemiology 26: 132-138.

Hauk K, \& Rice N. 2004 A longitudinal analysis of mental health mobility in Britain. Health Economics 13: 981-1001.

Hughes, G., \& McCormick, B. 1985. Migration Intentions in the UK: Which Households Want to Migrate and Which Succeed? The Economic Journal 95: Supplement: Conference papers, 113-23.

Hughes, G., \& McCormick, B. 1991. Do Council Housing Policies Reduce Migration Between Regions? Economic Journal 91: 919-937.

Kalliath, T. J., O’Driscoll, M. P. \& Brough, P. 2004. A confirmatory factor analysis of the General Health Questionnaire-12. Stress and Health 20: 11-20.

Layard, R. 2005. Happiness: Lessons From a New Science. New York and London: Penguin.

McCormick, B. 1997. Regional Unemployment and Labour Mobility in the UK. European Economic Review 41: 581-89.

McCulloch, A. 2001. Ward-level deprivation and individual social and economic outcomes in the British Household Panel Study. Environment and Planning A 33: 667-684.

Martin, A.J. 1999. Assessing the multidimensionality of the 12-item General Health Questionnaire. Psychological Reports 84: 927-935.

Norman, P., Boyle, P., \& Rees, P. 2005. Selective migration, health and deprivation: a longitudinal analysis. Social Science \& Medicine 60: 2755-2771.

Nowok, B., van Ham, M., Findlay, A.M., and Gayle, V. 2013. Does migration make you happy? A longitudinal study of internal migration and subjective wellbeing. Environment and Planning A 45(4): 986-1002.

Office for National Statistics. 2004. Census 2001: National report for England and Wales part 2. Crown Copyright.

Office for National Statistics. 2011. Measuring Subjective Well-being. Crown Copyright

Oswald, A.J. 1997. Happiness and Economic Performance. Economic Journal 107: 18151831. 
Pevalin, D.J. 2000. Multiple applications of the GHQ-12 in a general population sample: an investigation of long-term retest effects. Social Psychiatry and Epidemiology 35: 508-512.

Piccinelli, M., Bisoffi, G., Bon, M., Cunico, L. \& Tansella, M. 1993. Validity and test-retest reliability of the Italian version of the 12-item General Health Questionnaire in general practice : a comparison between three scoring methods. Comprehensive Psychiatry 34: 198205.

Pissarides, C., \& Wadsworth, J. 1989. Unemployment and the Inter-regional Mobility of Labour. Economic Journal 99: 739-755.

Politi, P., Piccinelli, M., \& Wilkinson, G. 1994. Reliability, validity and factor structure of the 12-item General Health Questionnaire among young males in Italy. Acta Psychiatrica Scandinavica 90: 432-437.

Popham, F., Boyle, P., O'Reilly, D., \& Leyland, A.H. 2010. Exploring the impact of selective migration on the deprivation-mortality gap within Greater Glasgow. Glasgow Centre for Population Health.

Propper, C., Jones, K., Bolster, A., Burgess, S., Johnston, R., \& Sarker, R. 2005. Local neighbourhood and mental health: Evidence from the UK. Social Science \& Medicine 20652083.

Rabe, B. 2011. Dual-earner Migration. Earnings gains, employment and self-selection.' Journal of Population Economics 24(2): 477-497.

Rabe, B, \& Taylor, M.P. 2012. Differences in opportunities? Wages, employment and house price effects on migration. Oxford Bulletin of Economics and Statistics 74(6): 831-855.

Schmidt, N., Kruse, J., \& Tress, W. 1999, Psychometric properties of the General Health Questionnaire (GHQ-12) in a German primary care sample. Acta Psychiatrica Scandinavica 100:462-468.

Shevlin, M. \& Adamson, G. 2005. Alternative factor models and factorial invariance of the GHQ-12: a large sample analysis using confirmatory factor analysis. Psychological Assessment 17: 231-236

Sjaastad, L.A. 1962. The Costs and Returns of Human Migration. The Journal of Political Economy 70(5): 80-93.

Stutzer, A. \& Frey, B.S. 2010. Recent advances in the economics of individual subjective well-being. Social Research 77(2): 679-714.

Taylor, M.F (ed), Brice J, Buck N, Prentice-Lane E. 2010. British Household Panel Survey User Manual Volume A: Introduction, Technical Report and Appendices. Colchester: University of Essex. 
Taylor, M. 2007. Tied Migration and Subsequent Employment: Evidence from Couples in Britain. Oxford Bulletin of Economics and Statistics 69(6): 795-818.

University of Essex. Institute for Social and Economic Research, British Household Panel Survey: Waves 1-18, 1991-2009 [computer file]. 7th Edition. Colchester, Essex: UK Data Archive [distributor], July 2010a. SN: 5151.

University of Essex. Institute for Social and Economic Research, British Household Panel Survey, Waves 1-18, 1991-2009: Conditional Access, Local Authority Districts [computer file]. 3rd Edition. Colchester, Essex: UK Data Archive [distributor], July 2010b. SN: 6027.

Verbeek, M. and Nijman, T.E. 1992. Testing for selectivity bias in panel data models. International Economic Review 33: 681-703.

Verheij, R. A., van de Mheen, D.H., de Bakker, D. H., Groenewegen, P. P., \& Mackenbach, J. P. 1998. Urban-Rural variations in health in the Netherlands: does selective migration play a part? Journal of Epidemiology and Community Health 52: 487-493.

Weich, S., Twigg, L., Lewis, G., \& Jones, K. 2005. Geographical variation in rates of common mental disorders in Britain: prospective cohort study. The British Journal of Psychiatry 187: 29-34.

Wooldridge, J. 2005. Simple solutions to the initial conditions problem in dynamic, nonlinear panel data models with unobserved heterogeneity. Journal of Applied Econometrics 20: 3954. 


\section{Tables}


Table I Migration and preference to move rates

MANCHESTER CENTRE

FOR HEALTH ECONOMIC

\begin{tabular}{|c|c|c|c|c|c|c|c|c|c|}
\hline & \multicolumn{3}{|l|}{ All } & \multicolumn{3}{|l|}{ Males } & \multicolumn{3}{|l|}{ Females } \\
\hline & All & $\begin{array}{l}\text { Preferred to } \\
\text { move }(\mathrm{t}-1)\end{array}$ & $\begin{array}{l}\text { Preferred not } \\
\text { to move (t-1) }\end{array}$ & All & $\begin{array}{l}\text { Preferred to } \\
\text { move (t-1) }\end{array}$ & $\begin{array}{l}\text { Preferred not } \\
\text { to move (t-1) }\end{array}$ & All & $\begin{array}{l}\text { Preferred to } \\
\text { move (t-1) }\end{array}$ & $\begin{array}{l}\text { Preferred not } \\
\text { to move (t-1) }\end{array}$ \\
\hline $\begin{array}{l}\text { Residential } \\
\text { Non-migrant }\end{array}$ & $\begin{array}{l}119,625 \\
(90.31)\end{array}$ & $\begin{array}{l}36,709 \\
(30.69)\end{array}$ & $\begin{array}{l}82,926 \\
(69.32)\end{array}$ & $\begin{array}{l}54,673 \\
(90.20)\end{array}$ & $\begin{array}{l}17,025 \\
(31.14)\end{array}$ & $\begin{array}{l}37,658 \\
(68.88)\end{array}$ & $\begin{array}{l}64,952 \\
(90.39)\end{array}$ & $\begin{array}{l}19,684 \\
(30.31)\end{array}$ & $\begin{array}{l}45,268 \\
(69.69)\end{array}$ \\
\hline Migrant & $\begin{array}{l}12,841 \\
(9.69)\end{array}$ & $\begin{array}{l}7,907 \\
(61.58)\end{array}$ & $\begin{array}{l}4,934 \\
(38.42)\end{array}$ & $\begin{array}{l}5,938 \\
(9.80)\end{array}$ & $\begin{array}{l}3,612 \\
(60.83)\end{array}$ & $\begin{array}{l}2,326 \\
(39.17)\end{array}$ & $\begin{array}{l}6,903 \\
(9.61)\end{array}$ & $\begin{array}{l}4,295 \\
(62.22)\end{array}$ & $\begin{array}{l}2,608 \\
(37.78)\end{array}$ \\
\hline
\end{tabular}

Percentages in parenthesi

Table II Average GHQ scores by migrant status and preference to move

\begin{tabular}{|c|c|c|c|c|c|c|c|c|c|c|c|c|c|c|c|c|c|c|}
\hline & \multicolumn{6}{|l|}{ All } & \multicolumn{6}{|c|}{ Males } & \multicolumn{6}{|c|}{ Females } \\
\hline & \multicolumn{2}{|l|}{ All } & \multicolumn{2}{|c|}{$\begin{array}{l}\text { Preferred to } \\
\text { move }(\mathrm{t}-1)\end{array}$} & \multicolumn{2}{|c|}{$\begin{array}{l}\text { Preferred not } \\
\text { to move } \\
(\mathrm{t}-1)\end{array}$} & \multicolumn{2}{|c|}{ All } & \multicolumn{2}{|c|}{$\begin{array}{l}\text { Preferred to } \\
\text { move }(\mathrm{t}-1)\end{array}$} & \multicolumn{2}{|c|}{$\begin{array}{l}\text { Preferred not } \\
\text { to move } \\
(\mathrm{t}-1)\end{array}$} & \multicolumn{2}{|c|}{ All } & \multicolumn{2}{|c|}{$\begin{array}{l}\text { Preferred to } \\
\text { move (t-1) }\end{array}$} & \multicolumn{2}{|c|}{$\begin{array}{l}\text { Preferred not } \\
\text { to move } \\
(\mathrm{t}-1)\end{array}$} \\
\hline & $\mathrm{t}$ & $\mathrm{t}-1$ & $\mathrm{t}$ & $\mathrm{t}-1$ & $\mathrm{t}$ & $t-1$ & $\mathrm{t}$ & $t-1$ & $\mathrm{t}$ & $t-1$ & $\mathrm{t}$ & $t-1$ & $\mathrm{t}$ & $t-1$ & $\mathrm{t}$ & $\mathrm{t}-1$ & $\mathrm{t}$ & $\mathrm{t}-1$ \\
\hline $\begin{array}{l}\text { Residential } \\
\text { Non- } \\
\text { migrant }\end{array}$ & 1.82 & 1.80 & 2.18 & 2.19 & 1.67 & 1.62 & 1.48 & 1.45 & 1.74 & 1.76 & 1.36 & 1.35 & 2.12 & 2.09 & 2.56 & 2.56 & 1.92 & 1.88 \\
\hline Migrant & 2.13 & 2.25 & 2.17 & 2.34 & 2.06 & 2.10 & 1.76 & 1.87 & 1.78 & 1.91 & 1.73 & 1.80 & 2.45 & 2.58 & 2.50 & 2.70 & 2.36 & 2.37 \\
\hline
\end{tabular}


Table III Ordered probit estimates for the effects of migration on GHQ score

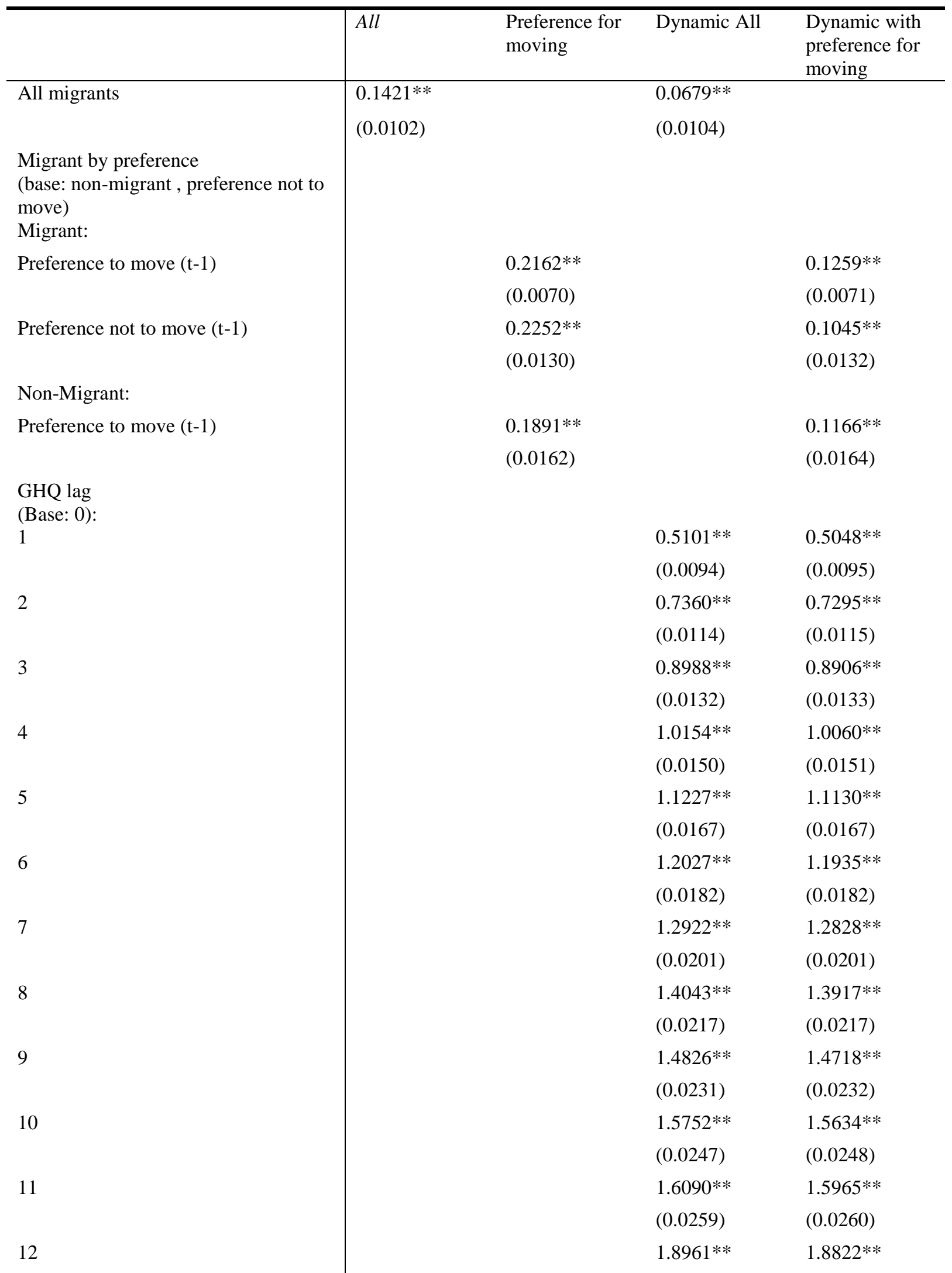




\begin{tabular}{|c|c|c|c|c|}
\hline & & & $(0.0238)$ & (0.0238) \\
\hline \multicolumn{5}{|l|}{ Cut-Point: } \\
\hline \multirow[t]{2}{*}{1} & 0.1036 & 0.1707 & 0.5245 & 0.5599 \\
\hline & $(0.0036)$ & $(0.0042)$ & $(0.0049)$ & $(0.0053)$ \\
\hline \multirow[t]{2}{*}{2} & 0.4544 & 0.5232 & 0.9269 & 0.9630 \\
\hline & $(0.0037)$ & $(0.0043)$ & $(0.0052)$ & $(0.0056)$ \\
\hline \multirow[t]{2}{*}{3} & 0.6839 & 0.7538 & 1.1937 & 1.2302 \\
\hline & (0.0039) & $(0.0045)$ & $(0.0055)$ & $(0.0059)$ \\
\hline \multirow[t]{2}{*}{4} & 0.8640 & 0.9348 & 1.4042 & 1.4410 \\
\hline & $(0.0041)$ & $(0.0047)$ & $(0.0057)$ & $(0.0061)$ \\
\hline \multirow[t]{2}{*}{5} & 1.0178 & 1.0893 & 1.5846 & 1.6216 \\
\hline & $(0.0043)$ & $(0.0049)$ & $(0.0060)$ & (0.0064) \\
\hline \multirow[t]{2}{*}{6} & 1.1604 & 1.2325 & 1.7520 & 1.7893 \\
\hline & $(0.0045)$ & $(0.0051)$ & $(0.0063)$ & (0.0067) \\
\hline \multirow[t]{2}{*}{7} & 1.2988 & 1.3714 & 1.9145 & 1.9519 \\
\hline & $(0.0048)$ & $(0.0054)$ & (0.0066) & $(0.0070)$ \\
\hline \multirow[t]{2}{*}{8} & 1.4361 & 1.5093 & 2.0755 & 2.1131 \\
\hline & $(0.0052)$ & $(0.0057)$ & $(0.0070)$ & $(0.0073)$ \\
\hline \multirow[t]{2}{*}{9} & 1.5725 & 1.6461 & 2.2353 & 2.2730 \\
\hline & $(0.0056)$ & $(0.0061)$ & $(0.0075)$ & $(0.0078)$ \\
\hline \multirow[t]{2}{*}{10} & 1.7250 & 1.7991 & 2.4140 & 2.4518 \\
\hline & $(0.0062)$ & $(0.0066)$ & $(0.0081)$ & $(0.0084)$ \\
\hline \multirow[t]{2}{*}{11} & 1.9037 & 1.9784 & 2.6233 & 2.6613 \\
\hline & $(0.0070)$ & $(0.0074)$ & $(0.0090)$ & (0.0093) \\
\hline \multirow[t]{2}{*}{12} & 2.1461 & 2.2214 & 2.9050 & 2.9431 \\
\hline & $(0.0086)$ & $(0.0089)$ & $(0.0106)$ & (0.0109) \\
\hline Observations & 132,466 & 132,466 & 132,466 & 132,466 \\
\hline
\end{tabular}

Standard errors in parentheses

Cut point estimates not presented

$* p<0.05, * * p<0.01$ 
Table IV Dynamic ordered probit estimates for model of GHQ scores with unobserved heterogeneity

\begin{tabular}{|c|c|c|c|c|c|c|}
\hline \multirow{2}{*}{ Migrant } & \multirow{2}{*}{$\begin{array}{l}\text { All } \\
0.0242 \\
(0.0124)\end{array}$} & \multirow[t]{2}{*}{ All } & \multicolumn{2}{|l|}{ Males } & \multicolumn{2}{|l|}{ Females } \\
\hline & & & $\begin{array}{l}0.0331 \\
(0.0188)\end{array}$ & & $\begin{array}{l}0.0175 \\
(0.0166)\end{array}$ & \\
\hline $\begin{array}{l}\text { Migrant/preference: } \\
\text { Migrant: } \\
\text { Preference to move (t-1) }\end{array}$ & & $\begin{array}{l}0.0075 \\
(0.0099)\end{array}$ & & $\begin{array}{l}-0.0115 \\
(0.0152)\end{array}$ & & $\begin{array}{l}0.0203 \\
(0.0131)\end{array}$ \\
\hline Preference not to move (t-1) & & $\begin{array}{l}0.0115 \\
(0.0155)\end{array}$ & & $\begin{array}{l}0.0083 \\
(0.0236)\end{array}$ & & $\begin{array}{l}0.0135 \\
(0.0206)\end{array}$ \\
\hline $\begin{array}{l}\text { Non-Migrant: } \\
\text { Preference to move (t-1) }\end{array}$ & & $\begin{array}{l}0.0541^{* *} \\
(0.0192)\end{array}$ & & $\begin{array}{l}0.0627 * \\
(0.0289)\end{array}$ & & $\begin{array}{l}0.0457 \\
(0.0258)\end{array}$ \\
\hline Preference not to move (t-1) & & & & & & \\
\hline Rho & $\begin{array}{l}0.3135 * * \\
(0.0073)\end{array}$ & $\begin{array}{l}0.3060^{* * *} \\
(0.0072)\end{array}$ & $\begin{array}{l}0.3277^{* *} \\
(0.0116)\end{array}$ & $\begin{array}{l}0.3222 * * \\
(0.0115)\end{array}$ & $\begin{array}{l}0.2979 * * \\
(0.0093)\end{array}$ & $\begin{array}{l}0.2885 * * \\
(0.0091)\end{array}$ \\
\hline Observations & 132,466 & 132,466 & 60,611 & 60,611 & 71,855 & 71,855 \\
\hline
\end{tabular}

Random effects ordered probit models

Gaussian random effects estimates via Gauss-Hermite quadrature (with 12 estimation points)

Migration is a residential move

Averages of time varying covariates (jointly significant, p-value $<0.001$ for all models), and year estimates not reported but available by author on request

$* p<0.05, * * p<0.01$ 
Table V Average marginal effects of migration and preference for each GHQ score probability

\begin{tabular}{|c|c|c|c|c|c|c|c|c|c|c|c|c|c|}
\hline & 0 & 1 & 2 & 3 & 4 & 5 & 6 & 7 & 8 & 9 & 10 & 11 & 12 \\
\hline $\begin{array}{l}\text { All } \\
\text { Migrant }\end{array}$ & $\begin{array}{l}-0.0083 \\
(0.0043)\end{array}$ & $\begin{array}{l}0.0010 \\
(0.0005)\end{array}$ & $\begin{array}{l}0.0012 \\
(0.0006)\end{array}$ & $\begin{array}{l}0.0010 \\
(0.0005)\end{array}$ & $\begin{array}{l}0.0009 \\
(0.0005)\end{array}$ & $\begin{array}{l}0.0008 \\
(0.0004)\end{array}$ & $\begin{array}{l}0.0007 \\
(0.0003)\end{array}$ & $\begin{array}{l}0.0006 \\
(0.0003)\end{array}$ & $\begin{array}{l}0.0005 \\
(0.0003)\end{array}$ & $\begin{array}{l}0.0005 \\
(0.0003)\end{array}$ & $\begin{array}{l}0.0004 \\
(0.0002)\end{array}$ & $\begin{array}{l}0.0004 \\
(0.0002)\end{array}$ & $\begin{array}{l}0.0005 \\
(0.0002)\end{array}$ \\
\hline $\begin{array}{l}\text { Migrant/preferenc } \\
\text { e: } \\
\text { Migrant: }\end{array}$ & & & & & & & & & & & & & \\
\hline $\begin{array}{l}\text { Preference to } \\
\text { move (t-1) } \\
\text { Preference not to } \\
\text { move (t-1) } \\
\text { Non-Migrant: }\end{array}$ & $\begin{array}{l}-0.0026 \\
(0.0034) \\
-0.0039 \\
(0.0053)\end{array}$ & $\begin{array}{l}0.0003 \\
(0.0004) \\
0.0005 \\
(0.0007)\end{array}$ & $\begin{array}{l}0.0004 \\
(0.0005) \\
0.0006 \\
(0.0007)\end{array}$ & $\begin{array}{l}0.0003 \\
(0.0004) \\
0.0005 \\
(0.0007)\end{array}$ & $\begin{array}{l}0.0003 \\
(0.0004) \\
0.0004 \\
(0.0006)\end{array}$ & $\begin{array}{l}0.0002 \\
(0.0003) \\
0.0004 \\
(0.0005)\end{array}$ & $\begin{array}{l}0.0002 \\
(0.0003) \\
0.0003 \\
(0.0004)\end{array}$ & $\begin{array}{l}0.0002 \\
(0.0002) \\
0.0003 \\
(0.0004)\end{array}$ & $\begin{array}{l}0.0002 \\
(0.0002) \\
0.0002 \\
(0.0003)\end{array}$ & $\begin{array}{l}0.0001 \\
(0.0002) \\
0.0002 \\
(0.0003)\end{array}$ & $\begin{array}{l}0.0001 \\
(0.0002) \\
0.0002 \\
(0.0003)\end{array}$ & $\begin{array}{l}0.0001 \\
(0.0002) \\
0.0002 \\
(0.0002)\end{array}$ & $\begin{array}{l}0.0001 \\
(0.0002) \\
0.0002 \\
(0.0003)\end{array}$ \\
\hline $\begin{array}{l}\text { Preference to } \\
\text { move }(\mathrm{t}-1)\end{array}$ & $\begin{array}{l}- \\
0.0185 * \\
* \\
(0.0066)\end{array}$ & $\begin{array}{l}0.0023 * \\
* \\
(0.0008)\end{array}$ & $\begin{array}{l}0.0026 * \\
* \\
(0.0009)\end{array}$ & $\begin{array}{l}0.0023 * \\
* \\
(0.0008)\end{array}$ & $\begin{array}{l}0.0020 * \\
* \\
(0.0006)\end{array}$ & $\begin{array}{l}0.0017 * \\
* \\
(0.0006)\end{array}$ & $\begin{array}{l}0.0015 * \\
* \\
(0.0005)\end{array}$ & $\begin{array}{l}0.0013 * \\
* \\
(0.0005)\end{array}$ & $\begin{array}{l}0.0011 * \\
* \\
(0.0004)\end{array}$ & $\begin{array}{l}0.0010 * \\
* \\
(0.0004)\end{array}$ & $\begin{array}{l}0.0009 * \\
* \\
(0.0003)\end{array}$ & $\begin{array}{l}0.0008 * \\
* \\
(0.0003)\end{array}$ & $\begin{array}{l}0.0010 * \\
* \\
(0.0004)\end{array}$ \\
\hline $\begin{array}{l}\text { Preference not to } \\
\text { move (t-1) (base) } \\
\text { Males }\end{array}$ & & & & & & & & & & & & & \\
\hline Migrant & $\begin{array}{l}-0.0110 \\
(0.0063)\end{array}$ & $\begin{array}{l}0.0021 \\
(0.0012)\end{array}$ & $\begin{array}{l}0.0018 \\
(0.0010)\end{array}$ & $\begin{array}{l}0.0014 \\
(0.0008)\end{array}$ & $\begin{array}{l}0.0011 \\
(0.0006)\end{array}$ & $\begin{array}{l}0.0009 \\
(0.0005)\end{array}$ & $\begin{array}{l}0.0008 \\
(0.0005)\end{array}$ & $\begin{array}{l}0.0006 \\
(0.0004)\end{array}$ & $\begin{array}{l}0.0005 \\
(0.0003)\end{array}$ & $\begin{array}{l}0.0005 \\
(0.0003)\end{array}$ & $\begin{array}{l}0.0004 \\
(0.0002)\end{array}$ & $\begin{array}{l}0.0003 \\
(0.0002)\end{array}$ & $\begin{array}{l}0.0004 \\
(0.0002)\end{array}$ \\
\hline $\begin{array}{l}\text { Migrant/preferenc } \\
\text { e: } \\
\text { Migrant: }\end{array}$ & & & & & & & & & & & & & \\
\hline $\begin{array}{l}\text { Preference to } \\
\text { move }(\mathrm{t}-1) \\
\text { Preference not to } \\
\text { move }(\mathrm{t}-1)\end{array}$ & $\begin{array}{l}0.0038 \\
(0.0051) \\
-0.0028 \\
(0.0079)\end{array}$ & $\begin{array}{l}-0.0007 \\
(0.0010) \\
0.0005 \\
(0.0015)\end{array}$ & $\begin{array}{l}-0.0006 \\
(0.0008) \\
0.0005 \\
(0.0013)\end{array}$ & $\begin{array}{l}-0.0005 \\
(0.0007) \\
0.0004 \\
(0.0010)\end{array}$ & $\begin{array}{l}-0.0004 \\
(0.0005) \\
0.0003 \\
(0.0009)\end{array}$ & $\begin{array}{l}-0.0003 \\
(0.0004) \\
0.0002 \\
(0.0007)\end{array}$ & $\begin{array}{l}-0.0003 \\
(0.0004) \\
0.0002 \\
(0.0006)\end{array}$ & $\begin{array}{l}-0.0002 \\
(0.0003) \\
0.0002 \\
(0.0005)\end{array}$ & $\begin{array}{l}-0.0002 \\
(0.0002) \\
0.0001 \\
(0.0004)\end{array}$ & $\begin{array}{l}-0.0002 \\
(0.0002) \\
0.0001 \\
(0.0003)\end{array}$ & $\begin{array}{l}-0.0001 \\
(0.0002) \\
0.0001 \\
(0.0003)\end{array}$ & $\begin{array}{l}-0.0001 \\
(0.0002) \\
0.0001 \\
(0.0002)\end{array}$ & $\begin{array}{l}-0.0001 \\
(0.0002) \\
0.0001 \\
(0.0003)\end{array}$ \\
\hline $\begin{array}{l}\text { Non-Migrant: } \\
\text { Preference to } \\
\text { move }(\mathrm{t}-1)\end{array}$ & $\begin{array}{l}- \\
0.0209 * \\
(0.0096)\end{array}$ & $\begin{array}{l}0.0040 * \\
(0.0019)\end{array}$ & $\begin{array}{l}0.0034 * \\
(0.0016)\end{array}$ & $\begin{array}{l}0.0027 * \\
(0.0013)\end{array}$ & $\begin{array}{l}0.0021 * \\
(0.0010)\end{array}$ & $\begin{array}{l}0.0018 * \\
(0.0008)\end{array}$ & $\begin{array}{l}0.0016^{*} \\
(0.0007)\end{array}$ & $\begin{array}{l}0.0012 * \\
(0.0006)\end{array}$ & $\begin{array}{l}0.0010 * \\
(0.0005)\end{array}$ & $\begin{array}{l}0.0009 * \\
(0.0004)\end{array}$ & $\begin{array}{l}0.0007 * \\
(0.0003)\end{array}$ & $\begin{array}{l}0.0006 * \\
(0.0003)\end{array}$ & $\begin{array}{l}0.0008 * \\
(0.0004)\end{array}$ \\
\hline $\begin{array}{l}\text { Preference not to } \\
\text { move (t-1) (base) } \\
\text { Females } \\
\text { Migrant }\end{array}$ & -0.0062 & 0.0005 & 0.0007 & 0.0007 & 0.0007 & 0.0006 & 0.0005 & 0.0004 & 0.0004 & 0.0004 & 0.0004 & 0.0004 & 0.0004 \\
\hline
\end{tabular}




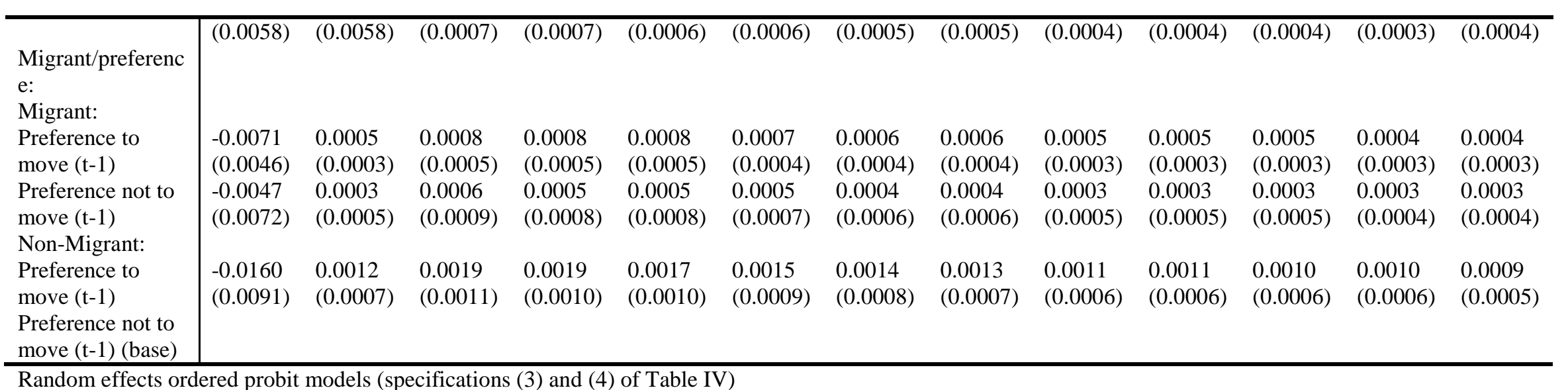

Random effects ordered probit models (specifications (3) and (4) of Table IV)

Average marginal effects; Standard errors (delta method) in parentheses.

$* p<0.05, * * p<0.01$

Migration is a residential move 


\section{Appendix}

Table A 1Summary statistics

\begin{tabular}{|c|c|c|}
\hline & number & percentage of sample \\
\hline \multicolumn{3}{|l|}{ Education: } \\
\hline None & 33,933 & 25.62 \\
\hline Degree or higher & 18,615 & 14.05 \\
\hline Some qual. & 22,933 & 60.33 \\
\hline \multicolumn{3}{|l|}{ Children: } \\
\hline None & 84,594 & 63.86 \\
\hline One & 23,644 & 17.85 \\
\hline Two & 17,906 & 13.52 \\
\hline Three or more & 6,322 & 4.77 \\
\hline Manual social class & 35,204 & 26.58 \\
\hline Age & 44 & \\
\hline \multicolumn{3}{|l|}{ Marital status: } \\
\hline Married & 76,599 & 57.83 \\
\hline Couple & 16,168 & 12.21 \\
\hline Widowed & 5,801 & 4.38 \\
\hline Divorced & 7,571 & 5.72 \\
\hline Single & 26,327 & 19.87 \\
\hline Ethnic Minority & 38,169 & 28.81 \\
\hline Male & 60,611 & 45.76 \\
\hline Physical health problems & 72,288 & 54.57 \\
\hline \multicolumn{3}{|l|}{ Region: } \\
\hline London & 8,708 & 6.57 \\
\hline South East & 20,701 & 15.63 \\
\hline South West & 9,938 & 7.50 \\
\hline East Anglia & 4,576 & 3.45 \\
\hline East Midlands & 9,064 & 6.84 \\
\hline West Midlands & 8,846 & 6.68 \\
\hline North West & 10,915 & 8.24 \\
\hline Yorks. \& Humber. & 9,400 & 7.10 \\
\hline North East & 6,479 & 4.89 \\
\hline Wales & 29,356 & 15.37 \\
\hline Scotland & 23,483 & 17.73 \\
\hline \multicolumn{3}{|l|}{ Job status: } \\
\hline Self Employed & 10,183 & 7.69 \\
\hline Employed & 79,321 & 59.88 \\
\hline Unemployed & 3,640 & 2.75 \\
\hline
\end{tabular}




\begin{tabular}{|c|c|c|}
\hline Retired & 19,275 & 14.55 \\
\hline Family care & 9,606 & 7.25 \\
\hline FT Education & 5,186 & 3.91 \\
\hline Long term sick & 4,499 & 3.40 \\
\hline Government scheme & 243 & 0.18 \\
\hline Other & 513 & 0.39 \\
\hline Log(income last month) & 6.723 & \\
\hline Total Migrations: & & \\
\hline 0 & 60,948 & 46.01 \\
\hline 1 & 32,662 & 24.66 \\
\hline 2 & 17,233 & 13.01 \\
\hline 3 & 9,112 & 6.88 \\
\hline 4 & 4,765 & 3.60 \\
\hline 5 & 3,428 & 2.59 \\
\hline $6+$ & 4,318 & 3.26 \\
\hline Total sample size & 132,466 & 100.00 \\
\hline
\end{tabular}

Table A 2 Full set of estimates for dynamic probit models of GHQ with unobserved heterogeneity

\begin{tabular}{|c|c|c|c|c|c|c|}
\hline & All & All & Males & & Females & \\
\hline Migrant & $\begin{array}{l}0.0242 * \\
(0.0124)\end{array}$ & & $\begin{array}{l}0.0331 * \\
(0.0188)\end{array}$ & & $\begin{array}{l}0.0175 \\
(0.0166)\end{array}$ & \\
\hline $\begin{array}{l}\text { Migrant/preference: } \\
\text { Migrant: } \\
\text { Preference to move } \\
\text { (t-1) }\end{array}$ & & $\begin{array}{l}0.00753 \\
(0.00994)\end{array}$ & & $\begin{array}{l}-0.0115 \\
(0.0152)\end{array}$ & & $\begin{array}{l}0.0203 \\
(0.0131)\end{array}$ \\
\hline $\begin{array}{l}\text { Preference not to } \\
\text { move (t-1) }\end{array}$ & & $\begin{array}{l}0.0115 \\
(0.0155)\end{array}$ & & $\begin{array}{l}0.00834 \\
(0.0236)\end{array}$ & & $\begin{array}{l}0.0135 \\
(0.0206)\end{array}$ \\
\hline Non-Migrant: & & & & & & \\
\hline $\begin{array}{l}\text { Preference to move } \\
\text { (t-1) }\end{array}$ & & $\begin{array}{l}0.0541 * * * \\
(0.0192)\end{array}$ & & $\begin{array}{l}0.0627 * * \\
(0.0289)\end{array}$ & & $\begin{array}{l}0.0457 \\
(0.0258)\end{array}$ \\
\hline $\begin{array}{l}\text { Preference not to } \\
\text { move (t-1) } \\
\text { GHQ Lag (base: } 0 \text { ) }\end{array}$ & & & & & & \\
\hline 1 & $\begin{array}{l}0.192 * * * \\
(0.0106)\end{array}$ & $\begin{array}{l}0.192 * * * \\
(0.0106)\end{array}$ & $\begin{array}{l}0.211 * * * \\
(0.0158)\end{array}$ & $\begin{array}{l}0.211 * * * \\
(0.0158)\end{array}$ & $\begin{array}{l}0.174 * * * \\
(0.0143)\end{array}$ & $\begin{array}{l}0.174 * * * \\
(0.0143)\end{array}$ \\
\hline 2 & $\begin{array}{l}0.308 * * * \\
(0.0128)\end{array}$ & $\begin{array}{l}0.308 * * * \\
(0.0128)\end{array}$ & $\begin{array}{l}0.348 * * * \\
(0.0196)\end{array}$ & $\begin{array}{l}0.348 * * * \\
(0.0196)\end{array}$ & $\begin{array}{l}0.276 * * * \\
(0.0169)\end{array}$ & $\begin{array}{l}0.276^{* * * *} \\
(0.0169)\end{array}$ \\
\hline
\end{tabular}




\begin{tabular}{|c|c|c|c|c|c|c|}
\hline \multirow[t]{2}{*}{3} & $0.378 * * *$ & $0.378 * * *$ & $0.403 * * *$ & $0.402 * * *$ & $0.357 * * *$ & $0.357 * * *$ \\
\hline & (0.0148) & $(0.0148)$ & $(0.0231)$ & $(0.0231)$ & (0.0194) & (0.0193) \\
\hline \multirow[t]{2}{*}{4} & $0.432 * * *$ & $0.432 * * *$ & $0.498 * * *$ & $0.497 * * *$ & $0.386 * * *$ & $0.386 * * *$ \\
\hline & $(0.0168)$ & $(0.0168)$ & $(0.0265)$ & $(0.0265)$ & $(0.0217)$ & $(0.0217)$ \\
\hline \multirow[t]{2}{*}{5} & $0.494 * * *$ & $0.493 * * *$ & $0.548 * * *$ & $0.547 * * *$ & $0.455 * * *$ & $0.455^{* * * *}$ \\
\hline & $(0.0185)$ & $(0.0185)$ & $(0.0298)$ & $(0.0298)$ & $(0.0236)$ & $(0.0236)$ \\
\hline \multirow[t]{2}{*}{6} & $0.504 * * *$ & $0.505^{* * *}$ & $0.615^{* * * *}$ & $0.615^{* * *}$ & $0.430 * * *$ & $0.432 * * *$ \\
\hline & $(0.0201)$ & $(0.0201)$ & $(0.0322)$ & $(0.0322)$ & $(0.0258)$ & $(0.0258)$ \\
\hline \multirow[t]{2}{*}{7} & $0.566 * * *$ & $0.565^{* * *}$ & $0.675^{* * *}$ & $0.674 * * *$ & $0.501 * * *$ & $0.500^{* * * *}$ \\
\hline & $(0.0222)$ & $(0.0221)$ & $(0.0369)$ & $(0.0369)$ & $(0.0277)$ & $(0.0277)$ \\
\hline \multirow[t]{2}{*}{8} & $0.638^{* * *}$ & $0.638 * * *$ & $0.692 * * *$ & $0.691 * * *$ & $0.601 * * *$ & $0.602 * * *$ \\
\hline & $(0.0238)$ & $(0.0238)$ & $(0.0398)$ & $(0.0398)$ & $(0.0297)$ & $(0.0297)$ \\
\hline \multirow[t]{2}{*}{9} & $0.657 * * *$ & $0.658 * * *$ & $0.778 * * *$ & $0.779 * * *$ & $0.589 * * *$ & $0.590 * * *$ \\
\hline & $(0.0255)$ & $(0.0255)$ & $(0.0434)$ & $(0.0434)$ & $(0.0316)$ & $(0.0316)$ \\
\hline \multirow[t]{2}{*}{10} & $0.675^{* * *}$ & $0.676^{* * *}$ & $0.730 * * *$ & $0.731 * * *$ & $0.639 * * *$ & $0.640 * * *$ \\
\hline & $(0.0273)$ & $(0.0273)$ & $(0.0486)$ & $(0.0486)$ & $(0.0331)$ & $(0.0331)$ \\
\hline \multirow[t]{2}{*}{11} & $0.656 * * *$ & $0.657 * * *$ & $0.755^{* * *}$ & $0.756 * * *$ & $0.603 * * *$ & $0.603 * * *$ \\
\hline & $(0.0287)$ & $(0.0287)$ & $(0.0511)$ & $(0.0511)$ & $(0.0348)$ & $(0.0348)$ \\
\hline \multirow[t]{2}{*}{12} & $0.795 * * *$ & $0.795 * * *$ & $0.919 * * *$ & $0.920 * * *$ & $0.730 * * *$ & $0.730^{* * *}$ \\
\hline & $(0.0274)$ & $(0.0274)$ & $(0.0490)$ & $(0.0490)$ & $(0.0332)$ & $(0.0332)$ \\
\hline \multicolumn{7}{|c|}{$\begin{array}{l}\text { GHQ (Initial, base: } \\
\text { 0)) }\end{array}$} \\
\hline \multirow[t]{2}{*}{1} & $0.326 * * *$ & $0.319 * * *$ & $0.341 * * *$ & $0.331 * * *$ & $0.312 * * *$ & $0.307 * * *$ \\
\hline & $(0.0174)$ & $(0.0172)$ & $(0.0260)$ & $(0.0258)$ & $(0.0233)$ & $(0.0231)$ \\
\hline \multirow[t]{2}{*}{2} & $0.425 * * *$ & $0.413 * * *$ & $0.460 * * *$ & $0.446 * * *$ & $0.394 * * *$ & $0.385^{* * *}$ \\
\hline & $(0.0212)$ & $(0.0211)$ & $(0.0321)$ & $(0.0319)$ & $(0.0283)$ & $(0.0280)$ \\
\hline \multirow[t]{2}{*}{3} & $0.552 * * *$ & $0.541 * * *$ & $0.577 * * *$ & $0.563 * * *$ & $0.526 * * *$ & $0.518 * * *$ \\
\hline & $(0.0247)$ & $(0.0245)$ & $(0.0380)$ & $(0.0378)$ & $(0.0324)$ & $(0.0321)$ \\
\hline \multirow[t]{2}{*}{4} & $0.657 * * *$ & $0.639 * * *$ & $0.708 * * *$ & $0.689 * * *$ & $0.613 * * *$ & $0.598 * * *$ \\
\hline & $(0.0288)$ & $(0.0286)$ & $(0.0451)$ & $(0.0449)$ & $(0.0373)$ & $(0.0369)$ \\
\hline \multirow[t]{2}{*}{5} & $0.692 * * *$ & $0.678 * * *$ & $0.819 * * *$ & $0.816 * * *$ & $0.614 * * *$ & $0.593 * * *$ \\
\hline & $(0.0318)$ & $(0.0315)$ & $(0.0517)$ & $(0.0514)$ & $(0.0401)$ & $(0.0398)$ \\
\hline \multirow[t]{2}{*}{6} & $0.740 * * *$ & $0.720 * * *$ & $0.817 * * *$ & $0.809 * * *$ & $0.685^{* * *}$ & $0.656 * * *$ \\
\hline & $(0.0355)$ & $(0.0352)$ & $(0.0576)$ & $(0.0573)$ & $(0.0450)$ & $(0.0446)$ \\
\hline \multirow[t]{2}{*}{7} & $0.743 * * *$ & $0.716^{* * *}$ & $0.844 * * *$ & $0.829 * * *$ & $0.694 * * *$ & $0.660 * * *$ \\
\hline & $(0.0427)$ & $(0.0424)$ & $(0.0799)$ & $(0.0795)$ & $(0.0502)$ & $(0.0497)$ \\
\hline \multirow[t]{2}{*}{8} & $0.801 * * *$ & $0.766^{* * *}$ & $0.907 * * *$ & $0.875^{* * *}$ & $0.725^{* * *}$ & $0.690 * * *$ \\
\hline & $(0.0434)$ & $(0.0431)$ & $(0.0707)$ & $(0.0704)$ & $(0.0549)$ & $(0.0544)$ \\
\hline \multirow[t]{2}{*}{9} & $0.899 * * *$ & $0.861 * * *$ & $0.926 * * *$ & $0.885^{* * *}$ & $0.869 * * *$ & $0.833 * * *$ \\
\hline & $(0.0527)$ & $(0.0523)$ & $(0.0894)$ & $(0.0890)$ & $(0.0648)$ & $(0.0642)$ \\
\hline 10 & $0.963 * * *$ & $0.933 * * *$ & $0.949 * * *$ & $0.925 * * *$ & $0.949 * * *$ & $0.916 * * *$ \\
\hline
\end{tabular}




\begin{tabular}{|c|c|c|c|c|c|c|}
\hline & $(0.0541)$ & $(0.0537)$ & $(0.0940)$ & $(0.0935)$ & $(0.0658)$ & $(0.0651)$ \\
\hline \multirow[t]{2}{*}{11} & $0.903 * * *$ & $0.870 * * *$ & $0.818 * * *$ & $0.800 * * *$ & $0.935 * * *$ & $0.892 * * *$ \\
\hline & $(0.0577)$ & $(0.0573)$ & $(0.103)$ & $(0.103)$ & $(0.0692)$ & $(0.0686)$ \\
\hline \multirow[t]{2}{*}{12} & $1.069 * * *$ & $1.038 * * *$ & $1.019 * * *$ & $0.981 * * *$ & $1.093 * * *$ & $1.066 * * *$ \\
\hline & $(0.0629)$ & $(0.0624)$ & $(0.115)$ & $(0.115)$ & $(0.0746)$ & $(0.0739)$ \\
\hline \multirow{2}{*}{$\begin{array}{l}\text { Physical health } \\
\text { problems }\end{array}$} & $0.133 * * *$ & $0.133 * * *$ & $0.141 * * *$ & $0.142 * * *$ & $0.127 * * *$ & $0.127 * * *$ \\
\hline & $(0.0104)$ & $(0.0104)$ & $(0.0158)$ & $(0.0158)$ & $(0.0138)$ & $(0.0138)$ \\
\hline \multicolumn{7}{|l|}{$\begin{array}{l}\text { Education (base: } \\
\text { none) }\end{array}$} \\
\hline \multirow[t]{2}{*}{ Degree or higher } & 0.0699 & 0.0695 & 0.105 & 0.108 & 0.0442 & 0.0421 \\
\hline & $(0.0705)$ & $(0.0705)$ & $(0.120)$ & $(0.120)$ & $(0.0871)$ & $(0.0871)$ \\
\hline \multirow[t]{2}{*}{ Some qual. } & 0.0353 & 0.0342 & 0.0515 & 0.0525 & 0.0202 & 0.0180 \\
\hline & $(0.0628)$ & $(0.0628)$ & (0.109) & (0.109) & $(0.0771)$ & $(0.0770)$ \\
\hline \multicolumn{7}{|l|}{$\begin{array}{l}\text { Children (base: } \\
\text { none) }\end{array}$} \\
\hline \multirow[t]{2}{*}{ One } & $0.0260 * *$ & $0.0265^{* *}$ & $0.0420 * *$ & $0.0424 * *$ & 0.0138 & 0.0144 \\
\hline & $(0.0129)$ & $(0.0129)$ & $(0.0200)$ & $(0.0200)$ & $(0.0171)$ & $(0.0171)$ \\
\hline \multirow[t]{2}{*}{ Two } & -0.00146 & -0.00112 & 0.0258 & 0.0257 & -0.0217 & -0.0211 \\
\hline & $(0.0158)$ & $(0.0158)$ & $(0.0243)$ & $(0.0243)$ & $(0.0210)$ & $(0.0210)$ \\
\hline \multirow[t]{2}{*}{ Three or more } & -0.00939 & -0.00890 & 0.0300 & 0.0295 & -0.0384 & -0.0375 \\
\hline & $(0.0240)$ & $(0.0240)$ & $(0.0373)$ & $(0.0373)$ & $(0.0315)$ & $(0.0315)$ \\
\hline \multirow[t]{2}{*}{ Age } & 0.00536 & 0.00319 & $0.0115^{*}$ & 0.00949 & 0.00271 & 0.000482 \\
\hline & $(0.00416)$ & $(0.00415)$ & $(0.00639)$ & $(0.00638)$ & $(0.00550)$ & $(0.00549)$ \\
\hline \multirow[t]{2}{*}{ Age Squared } & $-4.84 e-05$ & $-4.71 e-05$ & - & - & $3.60 \mathrm{e}-05$ & $3.69 \mathrm{e}-05$ \\
\hline & $(3.47 e-05)$ & $(3.47 \mathrm{e}-05)$ & $\begin{array}{l}0.000177 * * * \\
(5.48 \mathrm{e}-05)\end{array}$ & $\begin{array}{l}0.000177 * * * \\
(5.48 \mathrm{e}-05)\end{array}$ & $(4.51 \mathrm{e}-05)$ & $(4.51 \mathrm{e}-05)$ \\
\hline \multicolumn{7}{|l|}{$\begin{array}{l}\text { Marital status } \\
\text { (base: married) }\end{array}$} \\
\hline \multirow[t]{2}{*}{ Couple } & -0.00473 & -0.00508 & -0.0139 & -0.0141 & 0.00219 & 0.00171 \\
\hline & $(0.0188)$ & $(0.0188)$ & $(0.0291)$ & $(0.0291)$ & $(0.0247)$ & $(0.0247)$ \\
\hline \multirow[t]{2}{*}{ Widowed } & $0.369 * * *$ & $0.369 * * *$ & $0.270 * * *$ & $0.269 * * *$ & $0.396 * * *$ & $0.396 * * *$ \\
\hline & $(0.0391)$ & $(0.0391)$ & $(0.0740)$ & $(0.0740)$ & $(0.0464)$ & $(0.0464)$ \\
\hline \multirow[t]{2}{*}{ Divorced } & -0.0254 & -0.0264 & -0.0649 & -0.0663 & -0.00614 & -0.00723 \\
\hline & $(0.0270)$ & $(0.0270)$ & $(0.0471)$ & $(0.0472)$ & $(0.0332)$ & $(0.0332)$ \\
\hline \multirow[t]{2}{*}{ Single } & $0.119 * * *$ & $0.117 * * *$ & $0.134 * * *$ & $0.133 * * *$ & $0.114 * * *$ & $0.113 * * *$ \\
\hline & $(0.0208)$ & $(0.0208)$ & $(0.0331)$ & $(0.0331)$ & $(0.0269)$ & $(0.0269)$ \\
\hline \multicolumn{7}{|l|}{$\begin{array}{l}\text { Region (base: } \\
\text { London) }\end{array}$} \\
\hline \multirow[t]{2}{*}{ South East } & -0.0493 & -0.0485 & $-0.173 * * *$ & $-0.175^{* * *}$ & 0.0419 & 0.0446 \\
\hline & $(0.0431)$ & $(0.0431)$ & $(0.0645)$ & $(0.0645)$ & $(0.0581)$ & $(0.0581)$ \\
\hline \multirow[t]{2}{*}{ South West } & -0.0801 & -0.0786 & $-0.175^{*}$ & $-0.177 * *$ & -0.00104 & 0.00330 \\
\hline & $(0.0579)$ & $(0.0579)$ & $(0.0898)$ & $(0.0898)$ & $(0.0760)$ & $(0.0760)$ \\
\hline East Anglia & $-0.153 * *$ & $-0.151 * *$ & $-0.277 * *$ & $-0.279 * *$ & -0.0559 & -0.0510 \\
\hline
\end{tabular}




\begin{tabular}{|c|c|c|c|c|c|c|}
\hline & $(0.0738)$ & $(0.0738)$ & $(0.109)$ & $(0.109)$ & $(0.101)$ & $(0.101)$ \\
\hline East Midlands & $\begin{array}{l}-0.117 * \\
(0.0635)\end{array}$ & $\begin{array}{l}-0.116^{*} \\
(0.0636)\end{array}$ & $\begin{array}{l}-0.229 * * \\
(0.0948)\end{array}$ & $\begin{array}{l}-0.231 * * \\
(0.0948)\end{array}$ & $\begin{array}{l}-0.0295 \\
(0.0859)\end{array}$ & $\begin{array}{l}-0.0259 \\
(0.0859)\end{array}$ \\
\hline West Midlands & $\begin{array}{l}-0.0942 \\
(0.0696)\end{array}$ & $\begin{array}{l}-0.0932 \\
(0.0696)\end{array}$ & $\begin{array}{l}-0.290 * * * \\
(0.107)\end{array}$ & $\begin{array}{l}-0.293 * * * \\
(0.107)\end{array}$ & $\begin{array}{l}0.0433 \\
(0.0918)\end{array}$ & $\begin{array}{l}0.0465 \\
(0.0918)\end{array}$ \\
\hline North West & $\begin{array}{l}-0.0230 \\
(0.0678)\end{array}$ & $\begin{array}{l}-0.0229 \\
(0.0678)\end{array}$ & $\begin{array}{l}-0.266^{* *} \\
(0.104)\end{array}$ & $\begin{array}{l}-0.268 * * * \\
(0.104)\end{array}$ & $\begin{array}{l}0.151 * \\
(0.0897)\end{array}$ & $\begin{array}{l}0.153 * \\
(0.0897)\end{array}$ \\
\hline Yorks and Humber & $\begin{array}{l}-0.144 * * \\
(0.0701)\end{array}$ & $\begin{array}{l}-0.144 * * \\
(0.0701)\end{array}$ & $\begin{array}{l}-0.330 * * * \\
(0.109)\end{array}$ & $\begin{array}{l}-0.332 * * * \\
(0.109)\end{array}$ & $\begin{array}{l}-0.0115 \\
(0.0926)\end{array}$ & $\begin{array}{l}-0.0102 \\
(0.0925)\end{array}$ \\
\hline North East & $\begin{array}{l}-0.0341 \\
(0.0898)\end{array}$ & $\begin{array}{l}-0.0318 \\
(0.0897)\end{array}$ & $\begin{array}{l}-0.140 \\
(0.135)\end{array}$ & $\begin{array}{l}-0.139 \\
(0.135)\end{array}$ & $\begin{array}{l}0.0486 \\
(0.121)\end{array}$ & $\begin{array}{l}0.0531 \\
(0.121)\end{array}$ \\
\hline Wales & $\begin{array}{l}-0.168 * * \\
(0.0762)\end{array}$ & $\begin{array}{l}-0.167 * * \\
(0.0762)\end{array}$ & $\begin{array}{l}-0.375^{* * *} \\
(0.116)\end{array}$ & $\begin{array}{l}-0.376^{* * *} \\
(0.116)\end{array}$ & $\begin{array}{l}-0.0188 \\
(0.101)\end{array}$ & $\begin{array}{l}-0.0148 \\
(0.101)\end{array}$ \\
\hline Scotland & $\begin{array}{l}-0.159 * \\
(0.0852)\end{array}$ & $\begin{array}{l}-0.159 * \\
(0.0852)\end{array}$ & $\begin{array}{l}-0.429 * * * \\
(0.132)\end{array}$ & $\begin{array}{l}-0.431 * * * \\
(0.132)\end{array}$ & $\begin{array}{l}0.0310 \\
(0.112)\end{array}$ & $\begin{array}{l}0.0322 \\
(0.112)\end{array}$ \\
\hline $\begin{array}{l}\text { Job Status (base: } \\
\text { Self-Employed) } \\
\text { Employed }\end{array}$ & $\begin{array}{l}0.00764 \\
(0.0213)\end{array}$ & $\begin{array}{l}0.00788 \\
(0.0213)\end{array}$ & $\begin{array}{l}-0.00403 \\
(0.0279)\end{array}$ & $\begin{array}{l}-0.00385 \\
(0.0279)\end{array}$ & $\begin{array}{l}0.0429 \\
(0.0335)\end{array}$ & $\begin{array}{l}0.0429 \\
(0.0335)\end{array}$ \\
\hline Unemployed & $\begin{array}{l}0.401 * * * \\
(0.0305)\end{array}$ & $\begin{array}{l}0.401 * * * \\
(0.0305)\end{array}$ & $\begin{array}{l}0.393 * * * \\
(0.0408)\end{array}$ & $\begin{array}{l}0.393 * * * \\
(0.0408)\end{array}$ & $\begin{array}{l}0.434 * * * \\
(0.0465)\end{array}$ & $\begin{array}{l}0.434 * * * \\
(0.0465)\end{array}$ \\
\hline Retired & $\begin{array}{l}0.0531 * \\
(0.0283)\end{array}$ & $\begin{array}{l}0.0533 * \\
(0.0283)\end{array}$ & $\begin{array}{l}0.00668 \\
(0.0414)\end{array}$ & $\begin{array}{l}0.00667 \\
(0.0414)\end{array}$ & $\begin{array}{l}0.112 * * * \\
(0.0409)\end{array}$ & $\begin{array}{l}0.112 * * * \\
(0.0409)\end{array}$ \\
\hline Family Care & $\begin{array}{l}0.150 * * * \\
(0.0266)\end{array}$ & $\begin{array}{l}0.150 * * * \\
(0.0266)\end{array}$ & $\begin{array}{l}0.161 \\
(0.106)\end{array}$ & $\begin{array}{l}0.160 \\
(0.106)\end{array}$ & $\begin{array}{l}0.196 * * * \\
(0.0363)\end{array}$ & $\begin{array}{l}0.196 * * * \\
(0.0363)\end{array}$ \\
\hline Education & $\begin{array}{l}0.0249 \\
(0.0339)\end{array}$ & $\begin{array}{l}0.0249 \\
(0.0339)\end{array}$ & $\begin{array}{l}0.0394 \\
(0.0512)\end{array}$ & $\begin{array}{l}0.0387 \\
(0.0512)\end{array}$ & $\begin{array}{l}0.0460 \\
(0.0472)\end{array}$ & $\begin{array}{l}0.0459 \\
(0.0472)\end{array}$ \\
\hline Long-term Sick & $\begin{array}{l}0.524 * * * \\
(0.0333)\end{array}$ & $\begin{array}{l}0.524 * * * \\
(0.0333)\end{array}$ & $\begin{array}{l}0.486 * * * \\
(0.0477)\end{array}$ & $\begin{array}{l}0.486 * * * \\
(0.0477)\end{array}$ & $\begin{array}{l}0.575 * * * \\
(0.0478)\end{array}$ & $\begin{array}{l}0.574 * * * \\
(0.0478)\end{array}$ \\
\hline Govnt Training & $\begin{array}{l}0.0583 \\
(0.0869)\end{array}$ & $\begin{array}{l}0.0593 \\
(0.0869)\end{array}$ & $\begin{array}{l}0.0255 \\
(0.122)\end{array}$ & $\begin{array}{l}0.0248 \\
(0.123)\end{array}$ & $\begin{array}{l}0.116 \\
(0.124)\end{array}$ & $\begin{array}{l}0.119 \\
(0.124)\end{array}$ \\
\hline Other & $\begin{array}{l}0.118 * * \\
(0.0597)\end{array}$ & $\begin{array}{l}0.119 * * \\
(0.0597)\end{array}$ & $\begin{array}{l}0.228 * * \\
(0.0954)\end{array}$ & $\begin{array}{l}0.228 * * \\
(0.0954)\end{array}$ & $\begin{array}{l}0.0947 \\
(0.0781)\end{array}$ & $\begin{array}{l}0.0946 \\
(0.0781)\end{array}$ \\
\hline $\begin{array}{l}\text { Log(monthly } \\
\text { income) }\end{array}$ & $\begin{array}{l}-0.00481 \\
(0.00492)\end{array}$ & $\begin{array}{l}-0.00480 \\
(0.00492)\end{array}$ & $\begin{array}{l}-0.0169 * * \\
(0.00698)\end{array}$ & $\begin{array}{l}-0.0168 * * \\
(0.00698)\end{array}$ & $\begin{array}{l}0.00472 \\
(0.00697)\end{array}$ & $\begin{array}{l}0.00473 \\
(0.00697)\end{array}$ \\
\hline \multicolumn{7}{|l|}{$\begin{array}{l}\text { Waves (base: wave } \\
\text { 18) }\end{array}$} \\
\hline & $(0.0470)$ & $(0.0468)$ & (0.0703) & $(0.0701)$ & $(0.0633)$ & $(0.0630)$ \\
\hline 3 & $\begin{array}{l}0.0860 * * \\
(0.0437)\end{array}$ & $\begin{array}{l}0.0546 \\
(0.0436)\end{array}$ & $\begin{array}{l}-0.0177 \\
(0.0653)\end{array}$ & $\begin{array}{l}-0.0451 \\
(0.0652)\end{array}$ & $\begin{array}{l}0.173 * * * \\
(0.0589)\end{array}$ & $\begin{array}{l}0.138 * * \\
(0.0586)\end{array}$ \\
\hline
\end{tabular}




\begin{tabular}{|c|c|c|c|c|c|c|}
\hline 4 & $\begin{array}{l}0.0877 * * \\
(0.0410)\end{array}$ & $\begin{array}{l}0.0582 \\
(0.0409)\end{array}$ & $\begin{array}{l}-0.0404 \\
(0.0613)\end{array}$ & $\begin{array}{l}-0.0658 \\
(0.0612)\end{array}$ & $\begin{array}{l}0.193 * * * * \\
(0.0553)\end{array}$ & $\begin{array}{l}0.160 * * * \\
(0.0550)\end{array}$ \\
\hline 5 & $\begin{array}{l}0.0731^{*} \\
(0.0386)\end{array}$ & $\begin{array}{l}0.0462 \\
(0.0385)\end{array}$ & $\begin{array}{l}-0.0348 \\
(0.0576)\end{array}$ & $\begin{array}{l}-0.0580 \\
(0.0575)\end{array}$ & $\begin{array}{l}0.164 * * * \\
(0.0521)\end{array}$ & $\begin{array}{l}0.134 * * * \\
(0.0518)\end{array}$ \\
\hline 6 & $\begin{array}{l}0.0891 * * \\
(0.0363)\end{array}$ & $\begin{array}{l}0.0638 * \\
(0.0362)\end{array}$ & $\begin{array}{l}5.20 \mathrm{e}-05 \\
(0.0543)\end{array}$ & $\begin{array}{l}-0.0223 \\
(0.0542)\end{array}$ & $\begin{array}{l}0.164 * * * \\
(0.0489)\end{array}$ & $\begin{array}{l}0.137 * * * \\
(0.0486)\end{array}$ \\
\hline 7 & $\begin{array}{l}0.0711 * * \\
(0.0340)\end{array}$ & $\begin{array}{l}0.0482 \\
(0.0339)\end{array}$ & $\begin{array}{l}-0.0154 \\
(0.0508)\end{array}$ & $\begin{array}{l}-0.0357 \\
(0.0507)\end{array}$ & $\begin{array}{l}0.145 * * * \\
(0.0457)\end{array}$ & $\begin{array}{l}0.120^{* * * *} \\
(0.0455)\end{array}$ \\
\hline 8 & $\begin{array}{l}0.0368 \\
(0.0310)\end{array}$ & $\begin{array}{l}0.0149 \\
(0.0310)\end{array}$ & $\begin{array}{l}-0.0260 \\
(0.0465)\end{array}$ & $\begin{array}{l}-0.0456 \\
(0.0465)\end{array}$ & $\begin{array}{l}0.0907 * * \\
(0.0417)\end{array}$ & $\begin{array}{l}0.0674 \\
(0.0415)\end{array}$ \\
\hline 9 & $\begin{array}{l}-0.0286 \\
(0.0292)\end{array}$ & $\begin{array}{l}-0.0483 * \\
(0.0291)\end{array}$ & $\begin{array}{l}-0.0881 * * \\
(0.0439)\end{array}$ & $\begin{array}{l}-0.106 * * \\
(0.0439)\end{array}$ & $\begin{array}{l}0.0230 \\
(0.0392)\end{array}$ & $\begin{array}{l}0.00179 \\
(0.0390)\end{array}$ \\
\hline 10 & $\begin{array}{l}0.0724 * * * \\
(0.0263)\end{array}$ & $\begin{array}{l}0.0551 * * \\
(0.0262)\end{array}$ & $\begin{array}{l}0.0133 \\
(0.0396)\end{array}$ & $\begin{array}{l}-0.00219 \\
(0.0395)\end{array}$ & $\begin{array}{l}0.121 * * * \\
(0.0352)\end{array}$ & $\begin{array}{l}0.103 * * * \\
(0.0351)\end{array}$ \\
\hline 11 & $\begin{array}{l}0.0394 \\
(0.0241)\end{array}$ & $\begin{array}{l}0.0247 \\
(0.0241)\end{array}$ & $\begin{array}{l}-0.0150 \\
(0.0364)\end{array}$ & $\begin{array}{l}-0.0283 \\
(0.0363)\end{array}$ & $\begin{array}{l}0.0849 * * * \\
(0.0323)\end{array}$ & $\begin{array}{l}0.0691 \text { ** } \\
(0.0322)\end{array}$ \\
\hline 12 & $\begin{array}{l}0.00549 \\
(0.0230)\end{array}$ & $\begin{array}{l}-0.00671 \\
(0.0230)\end{array}$ & $\begin{array}{l}-0.0245 \\
(0.0347)\end{array}$ & $\begin{array}{l}-0.0353 \\
(0.0346)\end{array}$ & $\begin{array}{l}0.0319 \\
(0.0308)\end{array}$ & $\begin{array}{l}0.0186 \\
(0.0307)\end{array}$ \\
\hline 13 & $\begin{array}{l}-0.0434 * * \\
(0.0215)\end{array}$ & $\begin{array}{l}-0.0537 * * \\
(0.0215)\end{array}$ & $\begin{array}{l}-0.0747^{* *} \\
(0.0325)\end{array}$ & $\begin{array}{l}-0.0843 * * * \\
(0.0325)\end{array}$ & $\begin{array}{l}-0.0180 \\
(0.0286)\end{array}$ & $\begin{array}{l}-0.0285 \\
(0.0286)\end{array}$ \\
\hline 14 & $\begin{array}{l}-0.0471^{* *} \\
(0.0203)\end{array}$ & $\begin{array}{l}-0.0551 * * * \\
(0.0203)\end{array}$ & $\begin{array}{l}-0.0921^{* * *} \\
(0.0309)\end{array}$ & $\begin{array}{l}-0.0998^{* * *} \\
(0.0309)\end{array}$ & $\begin{array}{l}-0.0119 \\
(0.0270)\end{array}$ & $\begin{array}{l}-0.0201 \\
(0.0269)\end{array}$ \\
\hline 15 & $\begin{array}{l}-0.00251 \\
(0.0191)\end{array}$ & $\begin{array}{l}-0.00846 \\
(0.0191)\end{array}$ & $\begin{array}{l}-0.0411 \\
(0.0293)\end{array}$ & $\begin{array}{l}-0.0469 \\
(0.0293)\end{array}$ & $\begin{array}{l}0.0282 \\
(0.0253)\end{array}$ & $\begin{array}{l}0.0221 \\
(0.0253)\end{array}$ \\
\hline 16 & $\begin{array}{l}0.00811 \\
(0.0183)\end{array}$ & $\begin{array}{l}0.00395 \\
(0.0182)\end{array}$ & $\begin{array}{l}-0.0228 \\
(0.0280)\end{array}$ & $\begin{array}{l}-0.0270 \\
(0.0280)\end{array}$ & $\begin{array}{l}0.0320 \\
(0.0241)\end{array}$ & $\begin{array}{l}0.0279 \\
(0.0241)\end{array}$ \\
\hline Averages & $\begin{array}{l}-0.0289 \\
(0.0178)\end{array}$ & $\begin{array}{l}-0.0312 * \\
(0.0178)\end{array}$ & $\begin{array}{l}-0.0546^{* *} \\
(0.0274)\end{array}$ & $\begin{array}{l}-0.0572 * * \\
(0.0274)\end{array}$ & $\begin{array}{l}-0.00938 \\
(0.0235)\end{array}$ & $\begin{array}{l}-0.0112 \\
(0.0235)\end{array}$ \\
\hline Migrant & $\begin{array}{l}0.163 * * * \\
(0.0558)\end{array}$ & & $\begin{array}{l}0.175^{* *} \\
(0.0841)\end{array}$ & & $\begin{array}{l}0.150^{* *} \\
(0.0745)\end{array}$ & \\
\hline $\begin{array}{l}\text { Migrant/preference: } \\
\text { Migrant: } \\
\text { Preference to move } \\
\text { (t-1) }\end{array}$ & & $\begin{array}{l}0.257 * * * \\
(0.0222)\end{array}$ & & $\begin{array}{l}0.241 * * * \\
(0.0335)\end{array}$ & & $\begin{array}{l}0.275^{* * *} \\
(0.0297)\end{array}$ \\
\hline $\begin{array}{l}\text { Preference not to } \\
\text { move (t-1) }\end{array}$ & & $\begin{array}{l}0.359 * * * \\
(0.0657)\end{array}$ & & $\begin{array}{l}0.358 * * * \\
(0.100)\end{array}$ & & $\begin{array}{l}0.364 * * * \\
(0.0872)\end{array}$ \\
\hline Non-Migrant: & & & & & & \\
\hline $\begin{array}{l}\text { Preference to move } \\
\text { (t-1) }\end{array}$ & & $\begin{array}{l}0.0980 \\
(0.0737)\end{array}$ & & $\begin{array}{l}0.114 \\
(0.110)\end{array}$ & & $\begin{array}{l}0.0816 \\
(0.0996)\end{array}$ \\
\hline
\end{tabular}




\begin{tabular}{|c|c|c|c|c|c|c|}
\hline \multicolumn{7}{|l|}{$\begin{array}{l}\text { Preference not to } \\
\text { move }(\mathrm{t}-1)\end{array}$} \\
\hline Male & $\begin{array}{l}-0.172 * * * \\
(0.0138)\end{array}$ & $\begin{array}{l}-0.177 * * * \\
(0.0137)\end{array}$ & & & & \\
\hline \multicolumn{7}{|l|}{$\begin{array}{l}\text { Migrations (base: } \\
\text { 0) }\end{array}$} \\
\hline 1 & $\begin{array}{l}-0.00190 \\
(0.0167)\end{array}$ & $\begin{array}{l}-0.00274 \\
(0.0166)\end{array}$ & $\begin{array}{l}-0.00682 \\
(0.0255)\end{array}$ & $\begin{array}{l}-0.00628 \\
(0.0254)\end{array}$ & $\begin{array}{l}0.00104 \\
(0.0221)\end{array}$ & $\begin{array}{l}-0.00112 \\
(0.0219)\end{array}$ \\
\hline 2 & $\begin{array}{l}0.00581 \\
(0.0226)\end{array}$ & $\begin{array}{l}0.000857 \\
(0.0224)\end{array}$ & $\begin{array}{l}0.0159 \\
(0.0342)\end{array}$ & $\begin{array}{l}0.0126 \\
(0.0340)\end{array}$ & $\begin{array}{l}-0.00332 \\
(0.0300)\end{array}$ & $\begin{array}{l}-0.00948 \\
(0.0297)\end{array}$ \\
\hline 3 & $\begin{array}{l}0.0390 \\
(0.0295)\end{array}$ & $\begin{array}{l}0.0313 \\
(0.0292)\end{array}$ & $\begin{array}{l}0.0221 \\
(0.0437)\end{array}$ & $\begin{array}{l}0.0169 \\
(0.0435)\end{array}$ & $\begin{array}{l}0.0566 \\
(0.0399)\end{array}$ & $\begin{array}{l}0.0460 \\
(0.0395)\end{array}$ \\
\hline 4 & $\begin{array}{l}0.0436 \\
(0.0386)\end{array}$ & $\begin{array}{l}0.0324 \\
(0.0383)\end{array}$ & $\begin{array}{l}0.0663 \\
(0.0579)\end{array}$ & $\begin{array}{l}0.0579 \\
(0.0576)\end{array}$ & $\begin{array}{l}0.0339 \\
(0.0516)\end{array}$ & $\begin{array}{l}0.0213 \\
(0.0510)\end{array}$ \\
\hline 5 & $\begin{array}{l}0.00731 \\
(0.0456)\end{array}$ & $\begin{array}{l}0.00153 \\
(0.0452)\end{array}$ & $\begin{array}{l}-0.0221 \\
(0.0703)\end{array}$ & $\begin{array}{l}-0.0229 \\
(0.0699)\end{array}$ & $\begin{array}{l}0.0352 \\
(0.0597)\end{array}$ & $\begin{array}{l}0.0247 \\
(0.0591)\end{array}$ \\
\hline $6+$ & $\begin{array}{l}0.0536 \\
(0.0458)\end{array}$ & $\begin{array}{l}0.0557 \\
(0.0455)\end{array}$ & $\begin{array}{l}0.0265 \\
(0.0680)\end{array}$ & $\begin{array}{l}0.0314 \\
(0.0676)\end{array}$ & $\begin{array}{l}0.0742 \\
(0.0619)\end{array}$ & $\begin{array}{l}0.0731 \\
(0.0614)\end{array}$ \\
\hline Manual social class & $\begin{array}{l}-0.0769 * * * \\
(0.0149)\end{array}$ & $\begin{array}{l}-0.0787 * * * \\
(0.0148)\end{array}$ & $\begin{array}{l}-0.0940 * * * \\
(0.0214)\end{array}$ & $\begin{array}{l}-0.0950 * * * \\
(0.0213)\end{array}$ & $\begin{array}{l}-0.0490 * * \\
(0.0210)\end{array}$ & $\begin{array}{l}-0.0511^{* *} \\
(0.0208)\end{array}$ \\
\hline Ethnic Minority & $\begin{array}{l}-0.0193 \\
(0.0157)\end{array}$ & $\begin{array}{l}-0.0148 \\
(0.0156)\end{array}$ & $\begin{array}{l}-0.0681 * * * \\
(0.0237)\end{array}$ & $\begin{array}{l}-0.0653 * * * \\
(0.0235)\end{array}$ & $\begin{array}{l}0.0228 \\
(0.0209)\end{array}$ & $\begin{array}{l}0.0291 \\
(0.0207)\end{array}$ \\
\hline $\begin{array}{l}\text { Physical health } \\
\text { problems }\end{array}$ & $\begin{array}{l}0.242 * * * \\
(0.0199)\end{array}$ & $\begin{array}{l}0.223 * * * \\
(0.0198)\end{array}$ & $\begin{array}{l}0.248 * * * \\
(0.0304)\end{array}$ & $\begin{array}{l}0.229 * * * \\
(0.0304)\end{array}$ & $\begin{array}{l}0.239 * * * \\
(0.0263)\end{array}$ & $\begin{array}{l}0.221 * * * \\
(0.0261)\end{array}$ \\
\hline $\begin{array}{l}\text { Education (base: } \\
\text { none) }\end{array}$ & & & & & & \\
\hline Degree or higher & $\begin{array}{l}0.00599 \\
(0.0745)\end{array}$ & $\begin{array}{l}0.0180 \\
(0.0744)\end{array}$ & $\begin{array}{l}0.0540 \\
(0.126)\end{array}$ & $\begin{array}{l}0.0612 \\
(0.126)\end{array}$ & $\begin{array}{l}-0.0485 \\
(0.0930)\end{array}$ & $\begin{array}{l}-0.0333 \\
(0.0929)\end{array}$ \\
\hline Some qual. & $\begin{array}{l}-0.0355 \\
(0.0651)\end{array}$ & $\begin{array}{l}-0.0295 \\
(0.0650)\end{array}$ & $\begin{array}{l}-0.0175 \\
(0.112)\end{array}$ & $\begin{array}{l}-0.0154 \\
(0.112)\end{array}$ & $\begin{array}{l}-0.0445 \\
(0.0802)\end{array}$ & $\begin{array}{l}-0.0351 \\
(0.0802)\end{array}$ \\
\hline $\begin{array}{l}\text { Children (base: } \\
\text { none) }\end{array}$ & & & & & & \\
\hline One & $\begin{array}{l}0.0407 \\
(0.0282)\end{array}$ & $\begin{array}{l}0.0313 \\
(0.0280)\end{array}$ & $\begin{array}{l}0.0300 \\
(0.0440)\end{array}$ & $\begin{array}{l}0.0255 \\
(0.0438)\end{array}$ & $\begin{array}{l}0.0429 \\
(0.0370)\end{array}$ & $\begin{array}{l}0.0302 \\
(0.0368)\end{array}$ \\
\hline Two & $\begin{array}{l}0.0434 \\
(0.0321)\end{array}$ & $\begin{array}{l}0.0400 \\
(0.0320)\end{array}$ & $\begin{array}{l}0.00858 \\
(0.0494)\end{array}$ & $\begin{array}{l}0.00860 \\
(0.0492)\end{array}$ & $\begin{array}{l}0.0611 \\
(0.0425)\end{array}$ & $\begin{array}{l}0.0559 \\
(0.0422)\end{array}$ \\
\hline Three or more & $\begin{array}{l}0.168 * * * \\
(0.0464)\end{array}$ & $\begin{array}{l}0.159 * * * \\
(0.0461)\end{array}$ & $\begin{array}{l}0.134 * \\
(0.0709)\end{array}$ & $\begin{array}{l}0.124 * \\
(0.0707)\end{array}$ & $\begin{array}{l}0.175 * * * \\
(0.0617)\end{array}$ & $\begin{array}{l}0.169 * * * \\
(0.0613)\end{array}$ \\
\hline Age & $\begin{array}{l}-0.0163 * * * \\
(0.00518)\end{array}$ & $\begin{array}{l}-0.0148 * * * \\
(0.00517)\end{array}$ & $\begin{array}{l}-0.0254 * * * \\
(0.00804)\end{array}$ & $\begin{array}{l}-0.0241 * * * \\
(0.00802)\end{array}$ & $\begin{array}{l}-0.0132 * \\
(0.00683)\end{array}$ & $\begin{array}{l}-0.0117 * \\
(0.00680)\end{array}$ \\
\hline Age Squared & $\begin{array}{l}0.000137 * * * \\
(4.61 \mathrm{e}-05)\end{array}$ & $\begin{array}{l}0.000151 * * * \\
(4.59 \mathrm{e}-05)\end{array}$ & $\begin{array}{l}0.000280 * * * \\
(7.37 \mathrm{e}-05)\end{array}$ & $\begin{array}{l}0.000296 * * * \\
(7.36 \mathrm{e}-05)\end{array}$ & $\begin{array}{l}6.26 \mathrm{e}-05 \\
(5.94 \mathrm{e}-05)\end{array}$ & $\begin{array}{l}7.78 \mathrm{e}-05 \\
(5.91 \mathrm{e}-05)\end{array}$ \\
\hline
\end{tabular}




\begin{tabular}{|c|c|c|c|c|c|c|}
\hline & & & & & & \\
\hline $\begin{array}{l}\text { Marital status } \\
\text { (base: married) } \\
\text { Couple }\end{array}$ & $\begin{array}{l}0.0263 \\
(0.0306)\end{array}$ & $\begin{array}{l}0.00462 \\
(0.0305)\end{array}$ & $\begin{array}{l}0.0457 \\
(0.0460)\end{array}$ & $\begin{array}{l}0.0302 \\
(0.0459)\end{array}$ & $\begin{array}{l}0.000159 \\
(0.0413)\end{array}$ & $\begin{array}{l}-0.0261 \\
(0.0412)\end{array}$ \\
\hline Widowed & $\begin{array}{l}-0.243 * * * \\
(0.0532)\end{array}$ & $\begin{array}{l}-0.228 * * * \\
(0.0530)\end{array}$ & $\begin{array}{l}-0.128 \\
(0.103)\end{array}$ & $\begin{array}{l}-0.112 \\
(0.102)\end{array}$ & $\begin{array}{l}-0.319 * * * \\
(0.0636)\end{array}$ & $\begin{array}{l}-0.303 * * * \\
(0.0634)\end{array}$ \\
\hline Divorced & $\begin{array}{l}0.125 * * * \\
(0.0407)\end{array}$ & $\begin{array}{l}0.109 * * * \\
(0.0405)\end{array}$ & $\begin{array}{l}0.0714 \\
(0.0729)\end{array}$ & $\begin{array}{l}0.0576 \\
(0.0727)\end{array}$ & $\begin{array}{l}0.119 * * \\
(0.0495)\end{array}$ & $\begin{array}{l}0.103 * * \\
(0.0492)\end{array}$ \\
\hline Single & $\begin{array}{l}-0.0930 * * * \\
(0.0316)\end{array}$ & $\begin{array}{l}-0.0941 * * * \\
(0.0315)\end{array}$ & $\begin{array}{l}-0.151 * * * \\
(0.0492)\end{array}$ & $\begin{array}{l}-0.144 * * * \\
(0.0491)\end{array}$ & $\begin{array}{l}-0.0772 * \\
(0.0419)\end{array}$ & $\begin{array}{l}-0.0847 * * \\
(0.0417)\end{array}$ \\
\hline $\begin{array}{l}\text { Region (base: } \\
\text { London) }\end{array}$ & & & & & & \\
\hline South East & $\begin{array}{l}0.0108 \\
(0.0528)\end{array}$ & $\begin{array}{l}0.0233 \\
(0.0527)\end{array}$ & $\begin{array}{l}0.161 * * \\
(0.0793)\end{array}$ & $\begin{array}{l}0.170 * * \\
(0.0792)\end{array}$ & $\begin{array}{l}-0.0946 \\
(0.0710)\end{array}$ & $\begin{array}{l}-0.0787 \\
(0.0708)\end{array}$ \\
\hline South West & $\begin{array}{l}0.0168 \\
(0.0676)\end{array}$ & $\begin{array}{l}0.0411 \\
(0.0675)\end{array}$ & $\begin{array}{l}0.0633 \\
(0.104)\end{array}$ & $\begin{array}{l}0.0873 \\
(0.104)\end{array}$ & $\begin{array}{l}-0.0103 \\
(0.0892)\end{array}$ & $\begin{array}{l}0.0137 \\
(0.0890)\end{array}$ \\
\hline East Anglia & $\begin{array}{l}0.0355 \\
(0.0856)\end{array}$ & $\begin{array}{l}0.0713 \\
(0.0855)\end{array}$ & $\begin{array}{l}0.132 \\
(0.127)\end{array}$ & $\begin{array}{l}0.163 \\
(0.127)\end{array}$ & $\begin{array}{l}-0.0264 \\
(0.116)\end{array}$ & $\begin{array}{l}0.0132 \\
(0.116)\end{array}$ \\
\hline East Midlands & $\begin{array}{l}0.0750 \\
(0.0726)\end{array}$ & $\begin{array}{l}0.0960 \\
(0.0725)\end{array}$ & $\begin{array}{l}0.154 \\
(0.108)\end{array}$ & $\begin{array}{l}0.176 \\
(0.108)\end{array}$ & $\begin{array}{l}0.0214 \\
(0.0979)\end{array}$ & $\begin{array}{l}0.0416 \\
(0.0977)\end{array}$ \\
\hline West Midlands & $\begin{array}{l}0.0553 \\
(0.0779)\end{array}$ & $\begin{array}{l}0.0626 \\
(0.0778)\end{array}$ & $\begin{array}{l}0.230 * \\
(0.119)\end{array}$ & $\begin{array}{l}0.241 * * \\
(0.119)\end{array}$ & $\begin{array}{l}-0.0586 \\
(0.103)\end{array}$ & $\begin{array}{l}-0.0538 \\
(0.103)\end{array}$ \\
\hline North West & $\begin{array}{l}0.00594 \\
(0.0757)\end{array}$ & $\begin{array}{l}0.0295 \\
(0.0756)\end{array}$ & $\begin{array}{l}0.223^{*} \\
(0.116)\end{array}$ & $\begin{array}{l}0.245^{* *} \\
(0.116)\end{array}$ & $\begin{array}{l}-0.141 \\
(0.100)\end{array}$ & $\begin{array}{l}-0.115 \\
(0.100)\end{array}$ \\
\hline Yorks and Humber & $\begin{array}{l}0.0930 \\
(0.0783)\end{array}$ & $\begin{array}{l}0.110 \\
(0.0781)\end{array}$ & $\begin{array}{l}0.260 * * \\
(0.121)\end{array}$ & $\begin{array}{l}0.278^{* *} \\
(0.121)\end{array}$ & $\begin{array}{l}-0.0135 \\
(0.103)\end{array}$ & $\begin{array}{l}0.00240 \\
(0.103)\end{array}$ \\
\hline North East & $\begin{array}{l}0.0204 \\
(0.0976)\end{array}$ & $\begin{array}{l}0.0415 \\
(0.0975)\end{array}$ & $\begin{array}{l}0.0544 \\
(0.147)\end{array}$ & $\begin{array}{l}0.0719 \\
(0.147)\end{array}$ & $\begin{array}{l}0.00655 \\
(0.132)\end{array}$ & $\begin{array}{l}0.0298 \\
(0.132)\end{array}$ \\
\hline Wales & $\begin{array}{l}0.186^{* * *} \\
(0.0819)\end{array}$ & $\begin{array}{l}0.208^{* * *} \\
(0.0819)\end{array}$ & $\begin{array}{l}0.377 * * * \\
(0.125)\end{array}$ & $\begin{array}{l}0.399 * * * \\
(0.125)\end{array}$ & $\begin{array}{l}0.0559 \\
(0.109)\end{array}$ & $\begin{array}{l}0.0773 \\
(0.109)\end{array}$ \\
\hline Scotland & $\begin{array}{l}0.0774 \\
(0.0902)\end{array}$ & $\begin{array}{l}0.0951 \\
(0.0901)\end{array}$ & $\begin{array}{l}0.338 * * \\
(0.139)\end{array}$ & $\begin{array}{l}0.357 * * \\
(0.139)\end{array}$ & $\begin{array}{l}-0.102 \\
(0.119)\end{array}$ & $\begin{array}{l}-0.0843 \\
(0.119)\end{array}$ \\
\hline $\begin{array}{l}\text { Job Status (base: } \\
\text { Self-Employed) }\end{array}$ & & & & & & \\
\hline Employed & $\begin{array}{l}0.0373 \\
(0.0373)\end{array}$ & $\begin{array}{l}0.0229 \\
(0.0371)\end{array}$ & $\begin{array}{l}0.0802 * \\
(0.0472)\end{array}$ & $\begin{array}{l}0.0636 \\
(0.0471)\end{array}$ & $\begin{array}{l}-0.0963 \\
(0.0645)\end{array}$ & $\begin{array}{l}-0.109^{*} \\
(0.0641)\end{array}$ \\
\hline Unemployed & $\begin{array}{l}0.0335 \\
(0.0686)\end{array}$ & $\begin{array}{l}-0.00717 \\
(0.0683)\end{array}$ & $\begin{array}{l}0.0203 \\
(0.0859)\end{array}$ & $\begin{array}{l}-0.0127 \\
(0.0857)\end{array}$ & $\begin{array}{l}0.00562 \\
(0.120)\end{array}$ & $\begin{array}{l}-0.0386 \\
(0.119)\end{array}$ \\
\hline Retired & $\begin{array}{l}-0.0741 \\
(0.0523)\end{array}$ & $\begin{array}{l}-0.0814 \\
(0.0520)\end{array}$ & $\begin{array}{l}0.0329 \\
(0.0757)\end{array}$ & $\begin{array}{l}0.0241 \\
(0.0754)\end{array}$ & $\begin{array}{l}-0.261^{* * * *} \\
(0.0798)\end{array}$ & $\begin{array}{l}-0.268^{* * * *} \\
(0.0792)\end{array}$ \\
\hline Family Care & $\begin{array}{l}-0.0166 \\
(0.0522)\end{array}$ & $\begin{array}{l}-0.0237 \\
(0.0519)\end{array}$ & $\begin{array}{l}0.0357 \\
(0.233)\end{array}$ & $\begin{array}{l}0.0310 \\
(0.232)\end{array}$ & $\begin{array}{l}-0.120 \\
(0.0736)\end{array}$ & $\begin{array}{l}-0.131^{*} \\
(0.0731)\end{array}$ \\
\hline
\end{tabular}




\begin{tabular}{|c|c|c|c|c|c|c|}
\hline \multirow[t]{2}{*}{ Education } & $0.123 * *$ & $0.137^{* * *}$ & 0.104 & 0.126 & 0.0561 & 0.0649 \\
\hline & $(0.0611)$ & $(0.0609)$ & $(0.0890)$ & $(0.0890)$ & $(0.0904)$ & $(0.0899)$ \\
\hline \multirow[t]{2}{*}{ Long-term Sick } & $0.272 * * *$ & $0.276 * * *$ & $0.419 * * *$ & $0.425^{* * * *}$ & 0.0501 & 0.0532 \\
\hline & $(0.0585)$ & $(0.0582)$ & $(0.0807)$ & $(0.0804)$ & $(0.0901)$ & $(0.0895)$ \\
\hline \multirow[t]{2}{*}{ Govnt Training } & -0.0560 & -0.0539 & 0.00264 & -0.0117 & -0.216 & -0.191 \\
\hline & $(0.237)$ & $(0.236)$ & $(0.348)$ & $(0.347)$ & $(0.325)$ & $(0.324)$ \\
\hline \multirow[t]{2}{*}{ Other } & $0.345^{*}$ & $0.363^{* *}$ & 0.410 & 0.438 & 0.167 & 0.180 \\
\hline & $(0.177)$ & $(0.177)$ & $(0.275)$ & $(0.274)$ & $(0.235)$ & $(0.233)$ \\
\hline \multirow{2}{*}{$\begin{array}{l}\log (\text { monthly } \\
\text { income) }\end{array}$} & 0.0138 & 0.0158 & 0.00104 & 0.00685 & $0.0396 * * *$ & $0.0393 * * *$ \\
\hline & $(0.0109)$ & $(0.0109)$ & $(0.0168)$ & $(0.0168)$ & $(0.0152)$ & $(0.0151)$ \\
\hline \multicolumn{7}{|l|}{ Cut-point } \\
\hline \multirow[t]{2}{*}{1} & $0.557 * * *$ & $0.632 * * *$ & $0.452 * * *$ & $0.547 * * *$ & $0.760 * * *$ & $0.830 * * *$ \\
\hline & (0.0988) & $(0.0983)$ & $(0.152)$ & $(0.152)$ & $(0.138)$ & $(0.137)$ \\
\hline \multirow[t]{2}{*}{2} & $1.024 * * *$ & $1.099 * * *$ & $0.958 * * *$ & $1.053^{* * *}$ & $1.197 * * *$ & $1.267 * * *$ \\
\hline & $(0.0988)$ & $(0.0983)$ & $(0.152)$ & $(0.152)$ & $(0.138)$ & $(0.137)$ \\
\hline \multirow[t]{2}{*}{3} & $1.333 * * *$ & $1.408 * * *$ & $1.280 * * *$ & $1.374 * * *$ & $1.498 * * *$ & $1.568 * * *$ \\
\hline & $(0.0988)$ & $(0.0983)$ & $(0.152)$ & $(0.152)$ & $(0.138)$ & $(0.137)$ \\
\hline \multirow[t]{2}{*}{4} & $1.576^{* * *}$ & $1.651 * * *$ & $1.533 * * *$ & $1.628^{* * * *}$ & $1.735 * * *$ & $1.805 * * *$ \\
\hline & $(0.0989)$ & $(0.0984)$ & $(0.152)$ & $(0.152)$ & $(0.138)$ & $(0.137)$ \\
\hline \multirow[t]{2}{*}{5} & $1.784 * * *$ & $1.859 * * *$ & $1.747 * * *$ & $1.842^{* * * *}$ & $1.940 * * *$ & $2.009 * * *$ \\
\hline & $(0.0989)$ & $(0.0984)$ & $(0.152)$ & $(0.152)$ & (0.138) & $(0.137)$ \\
\hline \multirow[t]{2}{*}{6} & $1.976^{* * *}$ & $2.051 * * *$ & $1.947 * * *$ & $2.042^{* * * *}$ & $2.128 * * *$ & $2.198 * * *$ \\
\hline & $(0.0989)$ & $(0.0984)$ & $(0.152)$ & $(0.152)$ & $(0.138)$ & $(0.137)$ \\
\hline \multirow[t]{2}{*}{7} & $2.163 * * *$ & $2.238 * * *$ & $2.148 * * *$ & $2.243 * * *$ & $2.307 * * *$ & $2.376 * * *$ \\
\hline & $(0.0990)$ & $(0.0985)$ & $(0.152)$ & $(0.152)$ & $(0.138)$ & $(0.137)$ \\
\hline \multirow[t]{2}{*}{8} & $2.348 * * *$ & $2.423 * * *$ & $2.339 * * *$ & $2.433^{* * * *}$ & $2.489 * * *$ & $2.558 * * *$ \\
\hline & $(0.0990)$ & $(0.0985)$ & $(0.152)$ & $(0.152)$ & $(0.138)$ & $(0.137)$ \\
\hline \multirow[t]{2}{*}{9} & $2.531 * * *$ & $2.606 * * *$ & $2.526 * * *$ & $2.621^{* * * *}$ & $2.670 * * *$ & $2.740 * * *$ \\
\hline & (0.0990) & $(0.0986)$ & $(0.152)$ & $(0.152)$ & (0.138) & $(0.137)$ \\
\hline \multirow[t]{2}{*}{10} & $2.735^{* * *}$ & $2.810 * * *$ & $2.736 * * *$ & $2.831^{* * * *}$ & $2.872 * * *$ & $2.942 * * *$ \\
\hline & $(0.0991)$ & $(0.0986)$ & $(0.153)$ & $(0.152)$ & $(0.138)$ & $(0.137)$ \\
\hline \multirow[t]{2}{*}{11} & $2.974 * * *$ & $3.049 * * *$ & $2.964 * * *$ & $3.058^{* * * *}$ & $3.117 * * *$ & $3.186 * * *$ \\
\hline & $(0.0992)$ & $(0.0988)$ & $(0.153)$ & $(0.153)$ & (0.138) & $(0.137)$ \\
\hline \multirow[t]{2}{*}{12} & $3.294 * * *$ & $3.369 * * *$ & $3.268 * * *$ & $3.362^{* * * *}$ & $3.445 * * *$ & $3.514 * * *$ \\
\hline & $(0.0995)$ & (0.0990) & $(0.153)$ & $(0.153)$ & (0.139) & (0.138) \\
\hline \multirow[t]{2}{*}{ Rho } & $0.314 * * *$ & $0.306^{* * *}$ & $0.328 * * *$ & $0.322^{* * * *}$ & $0.298 * * *$ & $0.289 * * *$ \\
\hline & $(0.00732)$ & $(0.00721)$ & $(0.0116)$ & $(0.0115)$ & $(0.00932)$ & $(0.00913)$ \\
\hline Observations & 132,466 & 132,466 & 60,611 & 60,611 & 71,855 & 71,855 \\
\hline
\end{tabular}

Random effects probit models; Standard errors (delta method) in parentheses. Averages of time varying covariates are jointly significant, $\mathrm{p}$-value $<0.001$ for all models

$* p<0.05, * * p<0.01$ 